\title{
A Role of Low-Density Lipoprotein Receptor-Related Protein 4 (LRP4) in Astrocytic A $\beta$ Clearance
}

\author{
${ }^{\circ}$ Hongsheng Zhang, ${ }^{1}$ Wenbing Chen, ${ }_{1}^{1}$ Zhibing Tan, ${ }^{1}$ Lei Zhang, ${ }^{1}$ Zhaoqi Dong, ${ }^{1}$ Wanpeng Cui, ${ }^{1}$ Kai Zhao, ${ }^{1}$ \\ Hongsheng Wang, ${ }^{1}{ }^{\oplus}$ Hongyang Jing, ${ }^{1}$ Rangjuan Cao, ${ }^{1}$ Chae Kim, ${ }^{2}$ Jiri G. Safar, ${ }^{2,3}$ Wen-Cheng Xiong, ${ }^{1,4}$ and \\ ${ }^{(-1)}$ Lin $\mathrm{Mei}^{1,4}$ \\ ${ }^{1}$ Department of Neurosciences, School of Medicine, Case Western Reserve University, Cleveland, Ohio 44106, ${ }^{2}$ Department of Pathology, School of \\ Medicine, Case Western Reserve University, Cleveland, Ohio 44106, ${ }^{3}$ Department of Neurology, School of Medicine, Case Western Reserve \\ University, Cleveland, Ohio 44106, and ${ }^{4}$ Louis Stokes Cleveland Veterans Affairs Medical Center, Cleveland, Ohio 44106
}

Amyloid- $\beta(A \beta)$ deposition occurs years before cognitive symptoms appear and is considered a cause of Alzheimer's disease (AD). The imbalance of $A \boldsymbol{\beta}$ production and clearance leads to $\mathrm{A} \boldsymbol{\beta}$ accumulation and $\mathrm{A} \boldsymbol{\beta}$ deposition. Increasing evidence indicates an important role of astrocytes, the most abundant cell type among glial cells in the brain, in $A \beta$ clearance. We explored the role of lowdensity lipoprotein receptor-related protein 4 (LRP4), a member of the LDLR family, in AD pathology. We show that Lrp4 is specifically expressed in astrocytes and its levels in astrocytes were higher than those of $L d l r$ and $L r p 1$, both of which have been implicated in A $\beta$ uptake. LRP4 was reduced in postmortem brain tissues of AD patients. Genetic deletion of the Lrp4 gene augmented $\mathrm{A} \beta$ plaques in $5 \mathrm{xFAD}$ male mice, an $\mathrm{AD}$ mouse model, and exacerbated the deficits in neurotransmission, synchrony between the hippocampus and PFC, and cognition. Mechanistically, LRP4 promotes A $\beta$ uptake by astrocytes likely by interacting with ApoE. Together, our study demonstrates that astrocytic LRP4 plays an important role in A $\beta$ pathology and cognitive function.

Key words: Alzheimer's disease; amyloid- $\beta$; astrocyte; LRP4

Significance Statement

This study investigates how astrocytes, a type of non-nerve cells in the brain, may contribute to Alzheimer's disease (AD) development. We demonstrate that the low-density lipoprotein receptor-related protein 4 (LRP4) is reduced in the brain of $\mathrm{AD}$ patients. Mimicking the reduced levels in an AD mouse model exacerbates cognitive impairment and increases amyloid aggregates that are known to damage the brain. We show that LRP4 could promote the clearance of amyloid protein by astrocytes. Our results reveal a previously unappreciated role of LRP4 in AD development.

\section{Introduction}

Alzheimer's disease (AD) is the most common form of dementia among the elderly and one of the leading contributors to global disease burden (Alzheimer's Association, 2019). Patients with AD

\footnotetext{
Received Jan. 30, 2020; revised May 10, 2020; accepted May 16, 2020.

Author contributions: H.Z., J.G.S., W.-C.X., and L.M. designed research; H.Z., W. Chen, Z.T., and C.K. performed research; H.Z., L.Z., Z.D., W. Cui, K.Z., H.W., H.J., R.C., C.K., J.G.S., and W.-C.X. contributed unpublished reagents/analytic tools; H.Z., W. Chen, Z.T., C.K., J.G.S., W.-C.X., and L.M. analyzed data; H.Z. and L.M. wrote the first draft of the paper; H.Z. and L.M. edited the paper; H.Z. and L.M. wrote the paper.

Work in the L.M. laboratory was supported by AG051510, MH083317, NS090083, and NS082007. Work in the J.G.S. laboratory was supported by National Institutes of Health Grants RF1AG058267 and RF1AG061797. Human tissues were obtained from National Institutes of Health NeuroBioBank (University of Miami Brain Endowment Bank and Human Brain and Spinal Fluid Resource (enter). We thank Dr. David Holtzman (Washington University) and Dr. Lance Johnson (University of Kentucky) for ApoE-expressing astrocyte cell lines; Dr. Lin Gan for generating Lrp4-Cre ${ }^{\text {ERT2 }}$ mice; members of the L.M. and W.-C.X. laboratories for helpful discussion; and the patients' families, the CID Foundation, referring clinicians, and all the members of the National Prion Disease Pathology Surveillance Center for invaluable technical help.

The authors declare no competing financial interests.

Correspondence should be addressed to Lin Mei at lin.mei@case.edu.

https://doi.org/10.1523/JNEUROSCI.0250-20.2020

Copyright $(2020$ the authors
}

suffer from a decline in episodic memory with an inability to recall the recent past and eventual loss of long-term memories, loss of cognitive function, and changes in personality (Albert et al., 2011). Pathologic hallmarks of AD include the accumulation of extracellular amyloid- $\beta$ (A $\beta$ ) peptide into plaques and intracellular neurofibrillary tangles containing hyperphosphorylated tau, together with increased glial activation and neuronal loss (Hardy and Selkoe, 2002). Genetic risk factors of AD include APP, PSEN 1/2, as well as $A p o E$ (Hardy and Selkoe, 2002). Recent studies have revealed how ApoE regulates $\mathrm{A} \beta$ metabolism (Yamazaki et al., 2019). In particular, it could enhance $A \beta$ uptake and clearance by astrocytes (Kounnas et al., 1995; Beffert et al., 1999; Koistinaho et al., 2004; Jiang et al., 2008; Lee et al., 2012). In mice, ApoE4 impairs $\mathrm{A} \beta$ clearance without altering $\mathrm{A} \beta$ production (Castellano et al., 2011). On the other hand, $\mathrm{A} \beta$ uptake is more efficient in the presence of the ApoE3, compared with ApoE4 (Beffert et al., 1999). These observations suggest that impaired A $\beta$ clearance may be a mechanism for ApoE4 in increasing the vulnerability to AD. Nevertheless, it remains unclear exactly how ApoE's function is regulated. 
Increasing evidence indicates an important role of astrocytes, the most abundant cell type among glial cells in the brain, in $\mathrm{A} \beta$ clearance. First, in human AD brains, astrocytes contain A $\beta$-positive granules (Funato et al., 1998; Thal et al., 2000). In agreement, astrocytes are able to bind and uptake soluble and insoluble A $\beta$ (Wisniewski and Wegiel, 1991; Funato et al., 1998; Wyss-Coray et al., 2003; Nielsen et al., 2009; Chung et al., 2013; Jones et al., 2013; R. X. Liu et al., 2016) and degrade them via the late endolysosomal pathway (Shaffer et al., 1995; Wyss-Coray et al., 2003; Nielsen et al., 2009; Basak et al., 2012). Second, astrocytes of AD model mice are less efficient in clearing extracellular $\mathrm{A} \beta$ (R. X. Liu et al., 2016), whereas enhancing the astrocytic lysosome biogenesis facilitates $\mathrm{A} \beta$ clearance and attenuates amyloid plaque pathogenesis (Xiao et al., 2014; Iram et al., 2016). Third, A $\beta$ clearance is regulated by LDLR family members in particular LDLR and LRP1 (LDLR-related protein 1) (LaneDonovan et al., 2014; Lane-Donovan and Herz, 2017). Considering the abundance of astrocytes in the brain and their modulatory functions on multiple brain cells, they may represent a major mechanism for $\mathrm{A} \beta$ clearance.

LRP4 is a core member of the LDLR family, which have been implicated in $\mathrm{AD}$ pathogenesis by modulating $\mathrm{A} \beta$ metabolism (Holtzman et al., 2012; Lane-Donovan and Herz, 2017). LRP4 serves as a receptor for agrin, a factor used by motor neurons, and plays a critical role in the formation and maintenance of the neuromuscular junction (N. Kim et al., 2008; B. Zhang et al., 2008; Wu et al., 2012; Zong et al., 2012; Barik et al., 2014). In the brain, LRP4 has been implicated in synaptic transmission, LTP, and cognitive function (Gomez et al., 2014; Sun et al., 2016) and adult hippocampal neurogenesis (H. Zhang et al., 2019). Recently, we found that Lrp4 is highly, perhaps specifically, expressed in astrocytes in the PFC and hippocampus, regions vulnerable in $\mathrm{AD}$ (Sun et al., 2016). Considering astrocytes' roles in A $\beta$ metabolism, we explored the role of LRP4 in AD pathology. Intriguingly, the levels of $\operatorname{Lrp} 4$ in astrocytes were higher than those of $L d l r$ and $L r p 1$, but were reduced in postmortem brain tissues of AD patients. Remarkably, genetic deletion of the Lrp4 gene augmented $\mathrm{A} \beta$ plaques in $5 \mathrm{xFAD}$ mice, an $\mathrm{AD}$ mouse model and exacerbated the deficits in neurotransmission, synchrony between the hippocampus and PFC, and cognition. Further mechanistic studies suggest that LRP4 promotes astrocytic A $\beta$ uptake by serving as a receptor for ApoE. These observations reveal a novel function of LRP4 and a potential pathologic mechanism in AD development.

\section{Material and Methods}

Animals. 5xFAD transgenic mice (B6SJL-Tg (APPSwFlLon, PSEN1 ${ }^{\star}$ M146L ${ }^{\star}$ L286V) 6799Vas/Mmja) were from The Jackson Laboratory (MMRRC stock \#34 840-JAX) (Oakley et al., 2006), which express human APP and PSEN1 transgenes with five ADlinked mutations (the Swedish [K670N/M671L], Florida [I716V], and London [V717I] mutation in APP, and the M146L and L286V mutation in PSEN1) under the mouse Thy1 promoter. $5 x F A D$ mice were maintained as hemizygotes on a C57BL/6 background. Lrp4f/f (Wu et al., 2012), GFAP-Cre (Zhuo et al., 2001), Ai9 (Madisen et al., 2010), GFAP-CreERT2 (Casper et al., 2007), Neurod6-Cre (Goebbels et al., 2006), Thy1GFP (Feng et al., 2000), and Slc1a2-EGFP (Gong et al., 2003) were as described previously (Sun et al., 2016). Mice were grouphoused no more than 5 per cage in a room with a $12 \mathrm{~h}$ light/dark cycle with ad libitum access to water and rodent chow diet (Diet 1/4 7097, Harlan Teklad). The Lrp4-Cre ${ }^{\text {ERT2 }}$ mice were generated by Lin Gan (University of Rochester). Briefly, a targeting vector containing a 3' FRT flanked neo cassette and P2AGFP-CreERT2 cassette was inserted to exon 38. The construct was electroporated into C57BL/6J-derived embryonic stem cells. Correctly targeted embryonic stem cells were injected into blastocysts. The resulting chimeric animals were tested for germline transmission by crossing to C57BL/6J. Heterozygous animals were crossed subsequently to FLP recombinase expressing mice to remove the FRT site flanked PGK-neo cassette. Mice that no longer contained the FRT flanked PGK-neo cassette were then backcrossed to C57BL/6 6 to remove the FLP recombinase transgene. PCR genotyping with the following primers: $2 \mathrm{AGCEF}\left(5^{\prime}\right.$ GGCAT CGTGC CCATC CTGAT CGAGC TGA -3'), and 2AGCER (5' - GCCAG CTGCA CGCTG CCATC CTCGA TGT $-3^{\prime}$ ) will reveal a fragment size $500 \mathrm{bp}$. Male mice were used. Some mice were injected as previously described (Sun et al., 2016; Appel et al., 2018). Tamoxifen (10 mg/ml, Sigma Millipore, catalog \#T5648) was prepared in corn oil (Sigma Millipore, cata$\log$ \#C8267) mixed with ethanol (9:1 ratio). Mice were injected with $100 \mathrm{mg} / \mathrm{kg}$ tamoxifen (i.p. every other day 3 times).

Experiments with animals were approved by the Institutional Animal Care and Use Committee of Case Western Reserve University.

Antibodies. The information of primary antibodies used was as follows: rabbit anti-GFAP (Dako, catalog \#Z0334, PRID:AB_ 10013382, 1:1000 for immunohistochemistry [IHC]), mouse anti-NeuN (Millipore, catalog \#MAB377, PRID:AB_2341188, 1:200 for IHC), chicken anti-GFP (AVES, catalog \#GFP-1020, PRID:AB_10000240,1:1000 for IHC), mouse anti- $\beta$-actin (Cell Signaling Technology, catalog \#12262, PRID:AB_2566811, 1:5000 for Western blot), mouse anti-LRP4 (UC Davis/NIH NeuroMab Facility, catalog \#75-221, PRID:AB_2139030, 1:1000 for Western blot), goat anti-Ibal (Abcam, catalog \#ab5076, RRID:AB_2224402, 1:250 for IHC), mouse anti-APP (6E10) (BioLegend, catalog \#803001, PRID:AB_2564653, 1:1000 for Western blot), rabbit anti-APP (Sigma Millipore, catalog \#A8717, PRID:AB_258409,1:1000 for Western blot), rabbit antialdolase C (Abcam, catalog \#ab87122, PRID:AB_10673854, 1:200 for IHC), rabbit anti-S100 (Abcam, catalog \#ab868, PRID:AB_ 306716, 1:200 for IHC), rabbit anti-Oligo2 (Novus, catalog \#NBP128667, PRID:AB_1914109, 1:200 for IHC), and goat antiApoE (Menidian Life Science, catalog \#K74180B, PRID:AB_ 150544,1:1000 for Western blot). The information of secondary antibodies used was as follows: AlexaFluor-488-donke antimouse- IgG (Jackson ImmunoResearch Laboratories, catalog \#715-547-003, PRID:AB_2340851), AlexaFluor-594-donkey-antirabbit-IgG (Jackson ImmunoResearch Laboratories, catalog \#711-586-152, RRID:AB_2340622), AlexaFluor-488-donkey-antirabbit-IgG (Jackson ImmunoResearch Laboratories, catalog \#711-547-003, RRID:AB_2340620), AlexaFluor-488-donkey-antigoat-IgG (Jackson ImmunoResearch Laboratories, catalog \#705-547-003, RRID:AB_2340431), AlexaFluor-488-donkey-antichicken-IgG (Jackson ImmunoResearch Laboratories, catalog \#703-546-155, RRID:AB_2340376), all diluted by 10\% donkey serum in PBS 1:200 (Jackson ImmunoResearch Laboratories) for IHC; RDye680RD donkey anti-rabbit-IgG (LI-COR Biosciences, catalog \#926-68073, RRID:AB_10954442) and IRDye 800CW donkey anti-mouse-IgG (LI-COR Biosciences, catalog \#92632 212, RRID:AB_621847) secondary antibodies, both 1:10,000 were diluted by $10 \%$ milk in TBST for Western blot.

Cell culture and protein purification. Mouse primary astrocytes were cultured from postnatal day 3 mouse pups as previously described with modification (Sun et al., 2016). In brief, 
cortices were dissected in ice-cold calcium- and magnesium-free Hanks Balanced Salt Solution (HBSS) to remove meninges. Brain tissues were washed with HBSS, digested in $0.25 \%$ trypsin-EDTA and $0.2 \mathrm{mg} / \mathrm{ml} \mathrm{DNase}$ for $10 \mathrm{~min}$ at $37^{\circ} \mathrm{C}$, and dissociated by trituration with fire-polished pipettes in HBSS containing $0.4 \mathrm{mg} / \mathrm{ml}$ DNase. The mixture was filtered through a $40 \mu \mathrm{m}$ nylon mesh, pelleted at $900 \times g$ for $5 \mathrm{~min}$, and resuspended in a growth media containing DMEM, 10\% FBS, $1 \times$ Glutamax, and $1 \times$ penicillin/ streptomycin. Cells were then plated on a poly-L-lysine-coated T75 flask. The culture medium was changed after $8 \mathrm{~h}$, and every $3 \mathrm{~d}$ following the initial change. Once the cells reached confluence, they were shaken at $220 \mathrm{rpm}$ for $3 \mathrm{~h}$, and the medium was aspirated to remove less adherent microglial cells. Astrocytes were washed with PBS, detached from the plate using $0.05 \%$ trypsin-EDTA, and seeded on 12-well plates or $10 \mathrm{~cm}$ plates.

HEK293T cells (ATCC, PRID:CVCL_0063) were cultured in DMEM supplemented with $10 \%$ FBS, $1 \times$ penicillin/streptomycin. They were transfected with Flag-tagged LRP4-ECD constructs with $0.1 \%$ polyethyleneimine (Polysciences, catalog $\# 24765$, molecular weight 40,000) as previously described (H. Zhang et al., 2019). To collect secreted ECD proteins, the culture medium was changed to serum-free for $36 \mathrm{~h}$ before collection. The medium was concentrated using Amicon centrifugal filter unit (Millipore, catalog \#UFC803008), and Flag-tagged proteins were purified with Flag M2 beads (Sigma Millipore A2220), eluted with $100 \mathrm{~mm}$ glycine buffer, $\mathrm{pH} 3.8$, and neutralized with Tris-HCl buffer.

Immortalized mouse astrocytes expressing human ApoE2, ApoE3, and ApoE4 were gifts from David Holtzman (Washington University) and cultured as previously described (Morikawa et al., 2005). The culture medium was conditioned with a serum-free medium for $36 \mathrm{~h}$ and concentrated 20 times with Amicon centrifugal filter unit (Millipore, catalog \#UFC201024). The concentrated medium was run through a HiTrap heparin column on an AKTA Explorer A100 FPLC system (GE Healthcare). $\mathrm{NaCl}$ gradient from 0 to $1 \mathrm{M}$ Tris buffer was used to elute ApoE. ApoE was concentrated and quantified by ELISA against a standard curve derived from serial dilutions of recombinant ApoE3.

$q R T-P C R$. Total RNA was purified from the hippocampus or cultured astrocytes with TRizol (Invitrogen, catalog \#15596-026) according to the manufacturer's protocol. RNA $(3 \mu \mathrm{g})$ was reversetranscribed to cDNA with GoScript reverse transcription kit (Promega). qPCR was performed in the ABI Step-One Plus system (Applied Biosystems) using SYBR Green (QIAGEN). Relative expression was determined using the comparative $C_{t}$ model $\left(\Delta \Delta \mathrm{C}_{\mathrm{t}}\right)$ with glyceraldehyde 3-phosphate dehydrogenase (Gapdh) as a reference. Primers for individual genes were as follows: Vldlr (forward: 5' -ACGGC AGCGA TGAGG TCAAC TG-3', reverse: 5' - CAGAG CCATC AACAC AGTCT CG-3'); Ldlr (forward: 5' GAATC TACTG GTCCG ACCTG TC, reverse: 5'-CTGTC CAGTA GATGT TGCGG TG-3'); Lrp1 (forward: 5'-CGAGA GCCTT TGTGC TGGAT GA-3', reverse: $5^{\prime}$-CGGAT GTCCT TCTCA ATGAG GG-3'); Lrp1b (forward: 5'-GACTA TGTCC TCACC TGTGA TGG-3', reverse: $5^{\prime}$-ACAGC GACGA TTGTA GCACG GT-3'); Lrp2 (forward: 5'-CCAAT GGACT CACTC TGGAC CT- $3^{\prime}$, reverse: $5^{\prime}$-GAATG GAAGG CAGTG CTGAT GAC-3'); Lrp4 (forward: 5' -GTGTG GCAGA ACCTT GACAG TC-3', reverse: 5'-TACGG TCTGA GCCAT CCATT CC-3'); Lrp8 (forward: 5'-GTGGA AGTAG CCACC AATCG CA-3', reverse: $5^{\prime}$-CTGCT CATCA ATGAG GACCA CC-3'); App (forward: 5' -TCCGT GTGAT CTACG AGCGC AT-3', reverse: 5' GCCAA GACAT CGTCG GAGTA GT-3'); APP (forward: 5' CCTTC TCGTT CCTGA CAAGT GC-3', reverse: 5'-GGCAG
CAACA TGCCG TAGTC AT-3'); Bacel (forward: 5' -TGCTG CCATC ACTGA ATCGG AC-3', reverse: 5'-GGAAT GTGGG TCTGC TTCAC CA-3'); Bace2 (forward: 5'-GATTG GTGCG ACCGT GATGG AA-3', reverse: 5'-GTTGC TGGCT ATGTC TTCCG TG-3'); Psen 1 (forward: 5'-GAGAC TGGAA CACAA CCATA GCC-3', reverse: $5^{\prime}$-AGAAC ACGAG CCCGA AGGTG AT-3'); Psen2 (forward: 5'-CTGGT GTTCA TCAAG TACCT GCC-3', reverse: 5'-TTCTC TCCTG GGCAG TTTCC AC-3'); PSEN1 (forward: 5'-GCAGT ATCCT CGCTG GTGAA GA-3', reverse: 5'-CAGGC TATGG TTGTG TTCCA GTC-3'); and Gapdh (forward: 5' -CATCA CTGCC ACCCA GAAGA CTG-3', reverse: 5' -ATGCC AGTGA GCTTC CCGTT CAG-3').

Tissue harvest, processing, staining, histology, and morphology analysis. Hippocampal, cortical, and entorhinal cortical samples from unaffected subjects $(n=9)$ and from subjects with AD $(n=9)$ were obtained from the Human Brain and Spinal Fluid Resource Center and the University of Miami Brain Endowment Bank. The diagnosis of AD was confirmed by pathologic and clinical criteria (Khachaturian, 1985) as well as Braak neuropathological staging of Alzheimer-related changes (Braak and Braak, 1991). The human brain samples were processed as previously described (Cohen et al., 2015). Human brain tissues were homogenized with Mini-bead beater 16 Cell Disrupter (Biospec) in $15 \%(\mathrm{w} / \mathrm{v})$ TBS, pH 7.4, containing complete protease inhibitor cocktail (Roche Applied), $75 \mathrm{~s}$ three times. Samples were rehomogenized in $1 \%$ Sarkosyl $(10 \% \mathrm{w} / \mathrm{v}) 75 \mathrm{~s}$ one time and cleaned by centrifugation at $500 \times g$ for $5 \mathrm{~min}$. Aliquots of the supernatant were stored at $-80^{\circ} \mathrm{C}$ for future analysis. Protein concentration was measured by the BCA protein kit.

Mice were anesthetized and perfused transcardially with icecold PBS containing protease inhibitors. Brains were isolated and dissected into two hemibrains. Right hemibrains were dissected on ice to isolate cortex and hippocampus, which were snap-frozen in liquid nitrogen and stored at $-80^{\circ} \mathrm{C}$ until use. Left hemibrains were drop-fixed in 4\% PFA for $24 \mathrm{~h}$ and stored at $4^{\circ} \mathrm{C}$ in PBS containing $0.05 \%$ sodium azide. Tissues were sectioned $(40 \mu \mathrm{m}$ per section) using a vibratome (VT1000S, Leica Microsystems). Sections were sequentially collected and stored at $-20^{\circ} \mathrm{C}$ in cryoprotectant solution (FD Section Storage Solution) before staining. Free-floating sections were washed three times in PBS, followed by $1 \mathrm{~h}$ blocking in PBS with $10 \%$ donkey serum. Sections were incubated in PBS with $10 \%$ donkey serum and primary antibodies for $48 \mathrm{~h}$ at $4^{\circ} \mathrm{C}$, washed three times in PBS, and incubated in PBS with $10 \%$ donkey serum plus secondary antibodies for $2 \mathrm{~h}$ at room temperature.

Thioflavin S (Thio-S) staining for plaque and quantification were conducted as previously described (Wen et al., 2011; Youmans et al., 2012) by an investigator blind to the genotype beginning with the lateral-most section in the ROI, every sixth tissue section of six consecutive sections was used. Sections were washed in PBS (three times for $5 \mathrm{~min}$ each) and stained in $0.1 \%$ Thio-S (dissolved in 50\% EtOH plus 50\% PBS) for $10 \mathrm{~min}$ in the dark. Sections were destained in $80 \% \mathrm{EtOH}$ (twice for $3 \mathrm{~min}$ each) and 95\% $\mathrm{EtOH}$ (once for $3 \mathrm{~min}$ ) in the dark, washed in water (three times, each for $3 \mathrm{~min}$ ) in dark and mounted with antifade fluorescence mounting medium. Quantification of plaque deposition was performed as previously described (Youmans et al., 2012). Briefly, images were captured on a BZX slider scanner, exported with BZX viewer software, and converted to 8-bit grayscale using National Institutes of Health ImageJ software. Converted images were thresholded to highlight plaques and to diminish the background signal; each object identified after thresholding was examined individually to confirm it was indeed 
a plaque. Eight sections per mouse were quantified. The cortex and hippocampus in each image were outlined and analyzed with National Institutes of Health Image J software. Plaques $>5.5$ $\mu \mathrm{m}^{2}$ were quantified. Spine density was analyzed as previously described (H. Zhang et al., 2016).

Western and dot blot analysis. Brain tissues were homogenized in RIPA buffer containing the following (in $\mathrm{mM}$ ): 50 Tris$\mathrm{HCl}, \mathrm{pH}$ 7.4, $150 \mathrm{NaCl}, 2 \mathrm{EDTA}, 1 \mathrm{PMSF}, 50$ sodium fluoride, 1 sodium vanadate, 1 DTT with $1 \%$ sodium deoxycholate, $1 \%$ SDS and $1 \times$ protease inhibitor cocktails as previously described $(\mathrm{Hu}$ et al., 2018). Homogenates were resolved by Nu-PAGE $4 \%-12 \%$ Bis-Tris gel (Invitrogen, catalog \#NP0336BOX) and transferred to nitrocellulose membranes. Subsequently, blots were incubated in the TBS buffer containing $0.1 \%$ Tween-20 and 5\% milk for $1 \mathrm{~h}$ at room temperature before the addition of primary antibody for incubation overnight at $4^{\circ} \mathrm{C}$. After extensive wash, blots were incubated with secondary antibodies (LI-COR Biosciences) in the TBS buffer for $1 \mathrm{~h}$ at room temperature. Immunoreactive bands were imaged and quantified using the Odyssey Infrared Imaging System (LI-COR Biosciences, model 2800). Band density of interested proteins was normalized in relation to loading control.

Dot blot analysis was performed as previously described (Atagi et al., 2015). Proteins in PBS were spotted on a nitrocellulose membrane using a dot blot manifold apparatus (Bio-Rad). Membrane strips were blocked with $1 \%$ Block Ace (Bio-Rad) in PBS and incubated with the indicated proteins $12 \mathrm{~h}$ at $4^{\circ} \mathrm{C}$. Bound proteins were detected with biotin-conjugated primary and IRDye-conjugated.

Brain homogenization. Brain tissues were homogenized as previously described with modification (Youmans et al., 2011). Briefly, frozen tissues (100 mg/1 ml ice-cold TBS/PI buffer) were homogenized with Dounce homogenizers until no visible pieces were seen. The mixture was centrifuged at $12,000 \times g\left(4^{\circ} \mathrm{C}\right)$ for $30 \mathrm{~min}$; TBS-insoluble fractions were added $5 \mathrm{M}$ GDN/PI buffer at the same ratio and homogenized by sonication. The homogenates were rotated at room temperature for $6 \mathrm{~h}$ and subsequently centrifuged at $12,000 \times g$ for $30 \mathrm{~min}$. The supernatants were collected as the GDN-soluble fraction. All the procedures were performed on ice.

ELISA. $\mathrm{A} \beta_{1-40}$ and $\mathrm{A} \beta_{1-42}$ in TBS- and GDN-soluble brain homogenates were measured by the $\mathrm{A} \beta 40$ human ELISA kit (Invitrogen, catalog \#KHB3481) and the A $\beta 42$ Human ELISA kit (Invitrogen, catalog \#KHB3441), respectively.

Behavioral analysis. The Morris water maze test was performed as previously described (H. Zhang et al., 2019). Briefly, the test was conducted in a circular water tank (with a diameter of $120 \mathrm{~cm})$ filled with water $\left(22^{\circ} \mathrm{C}\right)$ and in the presence of a constellation of spatial cues visible to the mice. Nontoxic white powder paints were added to the water to make the surface opaque to hide the escape platform. The maze was virtually divided into four quadrants, with one containing a hidden escape platform (diameter $10 \mathrm{~cm}$ ) present $1 \mathrm{~cm}$ below the water surface. The training consisted of 5 consecutive days of testing with four trials per day; there was a recovery period of $20 \mathrm{~min}$ between the training trials. Mice were placed into the water with their nose pointing toward the wall in a random way to prevent strategy learning. Mice were given $60 \mathrm{~s}$ to search the platform, at which point the experimenter would guide the animal to the platform if necessary. Mice remained on the platform for $20 \mathrm{~s}$ and then were dried with a towel. For the probe test, $24 \mathrm{~h}$ after the last training period, the platform was removed and mice were given $60 \mathrm{~s}$ to swim; and the trajectory and amount of time spent in each quadrant were quantified using a video tracking system (Etho Vision, Noldus).

The Y maze test was performed as previously described $(\mathrm{H}$. Zhang et al., 2016): mice were placed at one arm end of Y maze and allowed to freely explore the three arms for $8 \mathrm{~min}$. During the multiple arm entries, mice showed a tendency to enter a less recently entered arm. The total number of arm entries and the number of triads were recorded to calculate the percentage of spontaneous alternation. The total distance is recorded to evaluate the locomotion. An entry count when all four limbs are within the arm, and the total entries $>8$ are included to calculate the spontaneous alternation.

A $\beta 42$ uptake and binding assay. FAM-A $\beta 42$ was purchased from AnaSpec, and the experiments were performed as previously described with modification (C. C. Liu et al., 2017). Briefly, primary astrocytes were incubated with FAM-A $\beta 42(500 \mathrm{nM})$ at $37^{\circ} \mathrm{C}$ in DMEM with $10 \%$ FBS. For FACS analysis and $\mathrm{A} \beta 42$ internalization, astrocytes were dissociated from the plate, and washed and suspended in PBS containing 1.5\% FBS, 1\% sodium azide, and 1\% PFA. Astrocytes were analyzed for fluorescence on a BD FACS caliber machine (BD Bioscience). For imaging analysis, astrocytes were washed with PBS three times, fixed with $4 \%$ PFA in room temperature for $10 \mathrm{~min}$, and stained with the antiGFAP antibody.

Oligomeric $\mathrm{A} \beta 42$ was prepared as previously described (Y. T. Lin et al., 2018). Briefly, A $\beta 42$ (Bachem, catalog \#H-1368) peptide was dissolved in $1 \% \mathrm{NH}_{4} \mathrm{OH}$ at $1 \mathrm{mg} / \mathrm{ml}$ and sonicated. Lyophilized $\mathrm{A} \beta 42$ was further dissolved in water, filtered $(0.22 \mu \mathrm{m})$, and incubated at $37^{\circ} \mathrm{C}$ for $24 \mathrm{~h}$ before use. Astrocytes derived from Lrp4f/f and GFAP-Lrp4f/f were seeded in 12-well plates for $4 \mathrm{~d}$ and incubated with oligomeric A $\beta 42(200 \mathrm{ng} / \mathrm{ml})$ for an additional $2 \mathrm{~d}$. Oligomeric A $\beta 42(200 \mathrm{ng} / \mathrm{ml})$ was added to media only without astrocytes to measure the total levels of $\mathrm{A} \beta 42$. The measurement of $\mathrm{A} \beta 42$ in culture medium was performed after $2 \mathrm{~d}$ of incubation by human A $\beta 42$ ELISA kit following the manufacturer's instructions. The relative remaining A $\beta 42$ levels were normalized by the total protein level of cell lysate measured by the BCA protein assay kit.

Electrophysiological recording. The whole-cell patch-clamp recording was performed as previously described (Sun et al., 2016; Wang et al., 2018). Briefly, brain slices of $300 \mu \mathrm{m}$ thickness were prepared with a vibratome (VT1200S, Leica Microsystems) in sectioning buffer of $4^{\circ} \mathrm{C}$ (in $\mathrm{mM}$ as follows: 120 choline-Cl, 2.5 $\mathrm{KCl}, 0.5 \mathrm{CaCl}_{2}, 7 \mathrm{MgCl}_{2}, 1.25 \mathrm{NaH}_{2} \mathrm{PO}_{4}, 26 \mathrm{NaHCO}_{3}$, and 25 glucose). After incubation in oxygenated ACSF (in $\mathrm{mM}$ as follows: $124 \mathrm{NaCl}, 2.5 \mathrm{KCl}, 2.5 \mathrm{CaCl}_{2}, 2 \mathrm{MgSO}_{4}, 1.25 \mathrm{NaH}_{2} \mathrm{PO}_{4}, 26$ $\mathrm{NaHCO}_{3}$, and 10 glucose) at $34^{\circ} \mathrm{C}$ for $30 \mathrm{~min}$ and recovery at room temperature for $1 \mathrm{~h}$, slices were recorded under perfusion $\left(2 \mathrm{ml} / \mathrm{min}, 32^{\circ} \mathrm{C}-34^{\circ} \mathrm{C}\right)$. The whole-cell recording was aided with infrared optics, using an upright microscope equipped with a $40 \times$ water-immersion lens (Axioskop 2 Plus, Carl Zeiss) and an infrared-sensitive CCD camera (C2400-75, Hamamatsu). For recording of mEPSCs, recording pipettes (input resistance: 3-5 $\mathrm{M} \Omega$ ) were filled with internal solution (in $\mathrm{mM}$ as follows: 125 K-gluconate, $5 \mathrm{KCl}, 10 \mathrm{HEPES}, 0.2 \mathrm{EGTA}, 1 \mathrm{MgCl}_{2}, 4 \mathrm{Mg}$-ATP, $0.3 \mathrm{Na}$-GTP, 10 phosphocreatine, $\mathrm{pH} 7.25,290-300 \mathrm{~mm}$ ), while $1 \mu \mathrm{M}$ TTX and $20 \mu \mathrm{m}$ bicuculine methiodide were added to the perfusion buffer to block action potentials and GABAA receptor-mediated currents.

LTP was recorded as described previously (Chen et al., 2010; Sun et al., 2016). Briefly, the SC-CA1 pathway was stimulated with a concentric bipolar electrode, and the fEPSPs were recorded in CA1 neurons in current clamp with ACSF-filled 
glass pipettes (1-5 M $\Omega$ ). Stimuli consisted of monophasic $100 \mu \mathrm{s}$ pulses of constant currents (with intensity adjusted to produce $\sim 30 \%$ of maximal amplitudes) at a frequency of $0.033 \mathrm{~Hz}$. The strength of synaptic transmission was determined by measuring the initial (10\%-60\% rising phase) slope of fEPSPs. LTP was induced by a train of 100 pulses at the same intensity in $1 \mathrm{~s}$. The level of LTP was determined at an average of 50-60 min after tetanus stimulation.

In vivo recording as described previously (Tan et al., 2018). Mice were anesthetized with ketamine/xylazine (Sigma Millipore, $0.1 \mathrm{ml} / 10 \times g$ body weight, i.p.), shaved on the skull, and positioned on a stereotaxic apparatus. After antiseptic treatment, the scalp was removed, and the exposed skull area was cleared using $1 \% \mathrm{H}_{2} \mathrm{O}_{2}$. Craniotomy was performed unilaterally above the prelimbic PFC (1.8 $\mathrm{mm}$ anterior, $0.4 \mathrm{~mm}$ lateral, 1.4 $\mathrm{mm}$ ventral), and ventral hippocampus (vHPC) $(3.1 \mathrm{~mm}$ posterior, $3.0 \mathrm{~mm}$ lateral, $3.9 \mathrm{~mm}$ ventral). Two sets of tetrodes were implanted in the PFC and vHPC, respectively. Tetrodes were made from $13-\mu \mathrm{m}$-diameter platinum (with $10 \%$ iridium) fine wire (California Fine Wire) and were attached to movable screw microdrives on a custom-made frame (L. Lin et al., 2006). Skull screws were placed over the cerebellum and olfactory bulb as ground and reference, respectively. After surgery, mice were allowed for recovery at least 1 week before recording. Local field potential (LFP) signals were recorded simultaneously from the vHPC and PFC at a sampling rate of $1 \mathrm{kHz}$. Movable microdrives were advanced at a rate of $30 \mu \mathrm{m}$ per day to record a spectrum of neurons. LFP signals were amplified, bandpass filtered (0.5$1000 \mathrm{~Hz}$ ), and digitized using the OmniPlex Neural Data Acquisition System (Plexon).

Data were imported into MATLAB (The MathWorks) for analysis using custom-written scripts. LFP recordings were processed in Neuroexplorer (Nex Technologies). Fourier transform of LFPs was performed, and data were then binned with a bin size as follows:

$$
\text { Bin Size }=\frac{1}{(2 \times \text { Maximum Frequency })}
$$

and the number of bins equal to 2 times the number of frequency values, which was set to 1024 (Stujenske et al., 2014). The coherence for frequencies, $f$, was calculated for PFC and vHPC, $x(t)$ and $y(t)$, as follows:

$$
\text { Coherence }_{x y}(f)=\frac{\left|S_{x y}(f)\right|^{2}}{S_{x x}(f) S_{y y}(f)}
$$

where $S_{x y}(f)$ is the cross-spectrum product of PFC and vHPC and $S_{x x}(f)$ and $S_{y y}(f)$ the auto-spectrum products from the two brain regions, respectively. The coherence was processed by a Gaussian filter with a bin size of 3 .

Experimental design and statistical analysis. Male mice were used for all experiments, except either sex was used for culturing astrocytes. The sample sizes chosen are based on our previous studies (Wen et al., 2011; Sun et al., 2016; H. Zhang et al., 2019). Data are mean \pm SEM. For two independent data comparisons, unpaired $t$ test was used to determine statistical significance. For multiple comparisons, ANOVA was used. No statistical analysis was used to determine sample size prior. Statistical analyses were performed using Excel 2016 (Microsoft) or Prism 6.0 (GraphPad Software). The numbers of biological replicates are described in the figure legends.

\section{Results}

\section{Reduced LRP4 protein in human AD brain tissues}

Cumulative evidence indicates that LDLR family members can contribute to $\mathrm{A} \beta$ metabolism in astrocytes (Kanekiyo et al., 2013). To test the LDLR family members' expression in astrocytes, we performed qPCR assay. Interestingly, Lrp4 mRNA level related to Gapdh was the highest among LDLR family members, followed by $\operatorname{Lrp2}$. The mRNA level of $\operatorname{Lrp} 4$ in astrocytes was 4to 10 -fold higher than that of Ldlr and $\operatorname{Lrp1}$ (Fig. $1 A$ ), suggesting a potential role of LRP4 in astrocytes. Next, we analyzed LRP4 protein levels in the postmortem brains of $\mathrm{AD}$ patients. Remarkably, LRP4 levels were reduced in the hippocampus, cortex, and entorhinal cortex of AD patients, compared with unaffected controls (Fig. $1 B, C$ ). The ages of $\mathrm{AD}$ patients and control subjects were similar, suggesting the LRP4 reduction was not due to age difference (Fig. 1D). In addition, there was no difference in autolysis times of the two groups of samples (Fig. 1E). These results showed that LRP4 protein levels were reduced in the various regions of the brains from $\mathrm{AD}$ patients.

Exacerbated amyloid pathology in Lrp4 mutant 5xFAD mice To examine whether LRP4 deficiency contributes to AD pathogenesis, we conditionally ablated the Lrp4 gene in 5xFAD mice, a well-characterized $\mathrm{AD}$ mouse model that recapitulated many AD-related phenotypes (Oakley et al., 2006). To confirm the deletion of Lrp4, we performed Western blot and found LRP4 was reduced in brain lysates of $5 x F A D ; G F A P-L r p 4 f / f$ mice, compared with $5 x F A D ; L r p 4 f / f$ mice (Fig. $2 A, B$ ). Next, we examined $\mathrm{A} \beta$ deposition by Thio-S staining, which was widely used to stain the amyloid plaques (Bussiere et al., 2004). No A $\beta$ plaque was detected in mice at 1.5 months, in agreement with previous reports (Oakley et al., 2006). However, at 6 months, A $\beta$ plaques were readily detected in 5xFAD;Lrp4f/f mice. Remarkably, Thio$\mathrm{S}$-positive area in $5 \mathrm{xFAD}$;GFAP-Lrp4f/f mice was larger than that of $5 x F A D ; L r p 4 f / f$ mice at 6 months in both cortex and hippocampus (Fig. $2 C, D$ ). In addition, soluble and insoluble of $\mathrm{A} \beta$ were assessed by ELISA following extraction of whole-brain tissues into TBS-soluble and insoluble (guanidine- $\mathrm{HCl}, \mathrm{GDN}$ ) fractions (Youmans et al., 2011). Consistent with increased $\mathrm{A} \beta$ deposition, insoluble $\mathrm{A} \beta_{1-40}$ and $\mathrm{A} \beta_{1-42}$ in guanidine fraction as well as the soluble fraction of $\mathrm{A} \beta_{1-42}$ were increased in $5 \mathrm{xFAD}$; GFAP-Lrp4f/f mice (Fig. 2E,F). These results demonstrate increased $\mathrm{A} \beta$ deposition and $\mathrm{A} \beta$ levels in 5xFAD;GFAP-Lrp4f/f mice, suggesting that LRP4 deficiency exacerbates amyloid pathogenesis in $5 x F A D$ mice.

Worsened cognitive deficits in LRP4 deficiency 5xFAD mice The clinical hallmark of AD is progressive memory loss (Selkoe and Hardy, 2016). To determine whether LRP4 deficiency alters cognitive deficits in $5 x F A D$ mice, mice were subjected to the $\mathrm{Y}$ maze test. As reported previously (Oakley et al., 2006), spontaneous alternations in $\mathrm{Y}$ maze were reduced in $5 \mathrm{xFAD}$ mice, compared with Lrp4f/f mice (Fig. $3 A, B$ ). Intriguingly, these deficits were worsened by $\operatorname{Lrp} 4$ deletion (compare 5xFAD;GFAP-Lrp4f/f mice with 5xFAD;Lrp4f/f mice) (Fig. 3B). As control, Lrp4 mutation had little effect on the total distance or number of arm entries in $\mathrm{Y}$ maze, which were similar among the four genotypes (Fig. 3C,D). These results suggest that LRP4 deficiency precipitated the working memory deficits of $5 x F A D$ mice. Next, we tested the spatial learning and memory using the Morris water maze. During the training phase, 5xFAD;Lrp4f/f and GFAPLrp4f/f mice had similar latency to locate the hidden platform, 
A

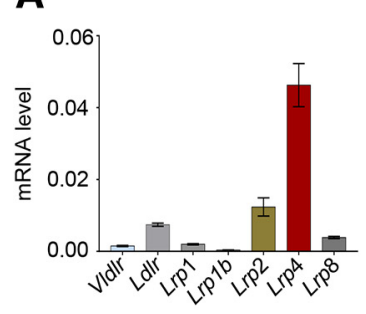

B

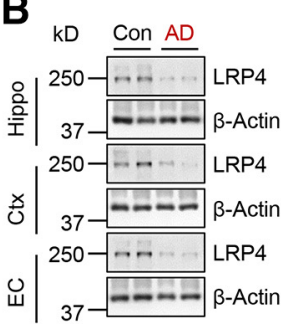

C

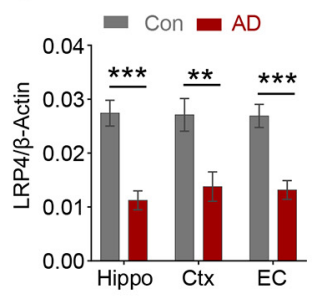

D

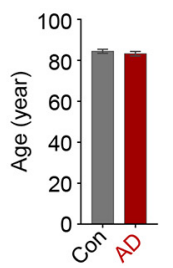

E

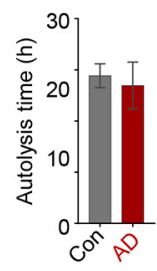

Figure 1. Reduced LRP4 protein in the AD postmortem brains. $A, q P C R$ of LDLR core members in primary cultured astrocytes. $n=4$ for each group. $B$, Western analysis of brain tissues from unaffected Con and AD. Three independent replicated experiments were performed. Con, controls; AD, Alzheimer's disease; Hippo, Hippocampus; Ctx, cortex; EC, entorhinal cortex. $C$, Quantification of $\mathrm{LRP} 4 / \beta$-actin ratio. $n=9$ brain samples for $\mathrm{AD}$ and 9 samples for control. Hippo: $t_{(16)}=5.446, p<0.0001 ; \mathrm{Ctx}_{(16)}=3.269, p=0.0048 ; \mathrm{EC}: t_{(16)}=4.974, p=0.0001$, unpaired $t$ test. $\boldsymbol{D}$, No difference in the ages of subjects between the two groups, $n=9$ for each group, $t_{(16)}=0.8205, p=0.424$, unpaired $t$ test. $\boldsymbol{E}$, No difference in autolysis time. $n=9$ for each group, $t_{(16)}=0.3709, p=0.7156$, unpaired $t$ test. Data are mean \pm SEM. ${ }^{* *} p<0.01, .{ }^{* * *} p<0.001$.

A

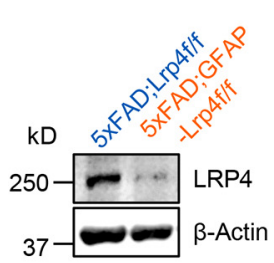

B

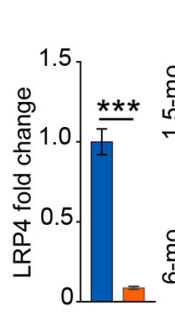

C 5xFAD;Lrp4f/f

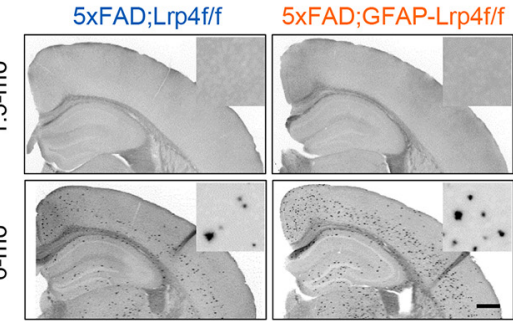

D

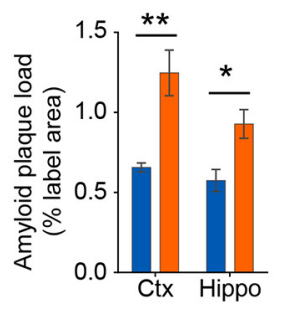

E

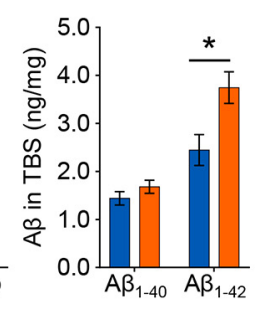

$\mathbf{F}$

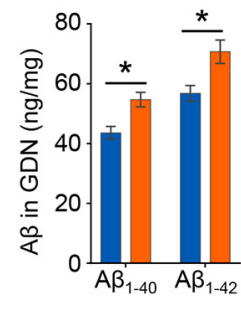

Figure 2. Exacerbated A $\beta$ pathology in LRP4 deficiency 5xFAD mice. $A$, Reduced LRP4 protein in 5xFAD;GFAP-Lrp4f/f mice compared with 5xFAD;Lrp4f/f. $\boldsymbol{B}$, Quantitative data in $A$. $n=3$ for each group. $t_{(4)}=11.2, p=0.0004$, unpaired $t$ test. $C$, $D$, Increased $A \beta$ deposition in 6-mo 5xFAD;GFAP-Lrp4f/f mice cortex and hippocampus, compared with 5xFAD;Lrp4f/f. Scale bar, $500 \mu \mathrm{m}$. Representative images $(\boldsymbol{C})$ and quantification of area covered by $\mathrm{A} \beta$ plaque $(\boldsymbol{D}) . n=4$ for each group. $\mathrm{Ctx}_{t_{(6)}}=4.061, p=0.0066$; Hippo: $t_{(6)}=3.121, p=0.0205$, unpaired $t$ test mo, month old. $E$, Increased TBS-soluble $A \beta_{1-42}$ in 6-mo 5xFAD;GFAP-Lrp4f/f mice brain, compared with 5xFAD;Lrp4f/f. $n=4$ for each group. $A \beta_{1-40}: t_{(6)}=1.231, p=0.2642 ; A \beta_{1-42}$ : $t_{(6)}=2.822, p=0.0303$, unpaired $t$ test. $\boldsymbol{F}$, Increased GDN-soluble $A \beta_{1-40}$ and $A \beta_{1-42}$ levels in 6-mo 5xFAD;GFAP-Lrp4f/f mice brain, compared with 5xFAD;Lrp4f/f. $n=4$ for each group. $\mathrm{A} \beta_{1-40}: t_{(6)}=3.455, p=0.0135 ; A \beta_{1-42}: t_{(6)}=2.557, p=0.0431$, unpaired $t$ test. Data are mean \pm SEM. ${ }^{*} p<0.05$, ${ }^{* *} p<0.01$, ${ }^{* * *} p<0.001$.

compared with the Lrp4f/f mice (Fig. 3E,F), in agreement with previous reports (Sun et al., 2016). However, 5xFAD;GFAPLrp4f/f mice were impaired in this task, exhibiting increased latency to locate the hidden platform (Fig. $3 E, F)$. During the probe test, 5xFAD;GFAP-Lrp4f/f mice displayed reduced frequency crossing the hidden platform, spent less time in the target quadrant, compared with other groups (Fig. $3 G, H$ ). The velocity among the four was no different during the test (Fig. 3I). Thus, these data demonstrate that LRP4 deficiency exacerbates spatial learning and memory deficits in $5 x F A D$ mice.

\section{Exacerbated synaptic deficits in $\operatorname{Lrp4}$ mutant AD mice}

To determine whether LRP4 deficiency alters synaptic transmission, we measured mEPSCs of CA1 neurons in hippocampal slices. We found that mEPSC frequency, but not amplitude, was reduced in GFAP-Lrp4f/f slices, compared with littermate Lrp4f/ $\mathrm{f}$ slices (Fig. 4A-C), in agreement with our previous report (Sun et al., 2016). mEPSC frequency and amplitude were reduced in 5xFAD;Lrp4f/f slices, compared with Lrp4f/f slices (Fig. 4A-C), which are in agreement with previous reports (Kimura and Ohno, 2009; Crouzin et al., 2013). Noticeably, LRP4 deficiency further reduced mEPSC frequency and amplitude, compared with $5 \mathrm{xFAD}$;GFAP-Lrp4f/f slices and 5xFAD;Lrp4f/f slices (Fig. $4 A-C$ ). We further investigated the effect of LRP4 deficiency on LTP, a cellular model of learning and memory (Malenka and Bear, 2004). The slopes of fEPSPs in GFAP-Lrp4f/f and $5 x F A D ; L r p 4 f / f$ slices were reduced compared with Lrp4f/f slices, suggesting impaired synaptic plasticity in CA1. The impairments were worsened in $5 \mathrm{xFAD}$;GFAP-Lrp4f/f slices (Fig. $4 D, E$ ). The deficiency of LTP was further suppressed in 5xFAD;GFAP-Lrp4f/f slices, compared with 5xFAD;Lrp4f/f slices and Lrp4f/f slices (Fig. $4 F$ ). These results indicate that LRP4 deficiency exacerbates the synaptic plasticity deficits in $5 x F A D$ mice.

To examine whether LRP4 deficiency exacerbates synaptic loss in $5 \mathrm{xFAD}$ mice, we generated compound mice carrying Thy1-GFPm that enables labeling excitatory neurons by GFP (Feng et al., 2000). The spine density of both apical oblique and basal shaft dendrites of CA1 neurons were reduced in 5xFAD; Lrp4f/f mice; and this reduction was further decreased in 5xFAD;GFAP-Lrp4f/f hippocampus (Fig. 4G,H). Thus, these results demonstrate LRP4 deficiency exacerbates synapse loss in 5xFAD mice.

\section{Further weakened hippocampal-PFC connectivity in 5xFAD mice by LRP4 deficiency}

Hippocampus and PFC are vulnerable in AD and damages in these regions are thought to contribute to cognition decline (Sampath et al., 2017). First, we investigated whether the hippocampus-PFC connectivity was impaired in $5 \mathrm{xFAD}$ mice and whether the impairment could be exacerbated by LRP4 deficiency. To this end, we recorded LFPs in both the vHPC and $\mathrm{PFC}$ of free-moving mice by implanted tetrodes as described in our recent study (Tan et al., 2018). vHPC neurons are known to project to the PFC (Swanson, 1981; Jay et al., 1989); however, whether this projection is impaired in $\mathrm{AD}$ mouse models was unclear. Remarkably, we found that the coherence of vHPC and 
A

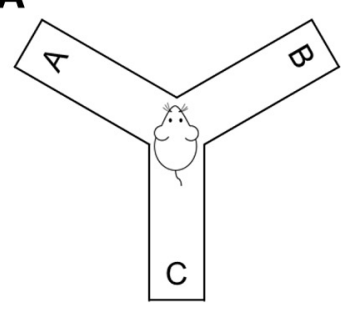

B

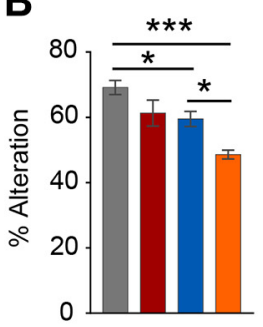

C

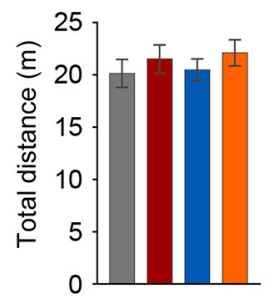

D

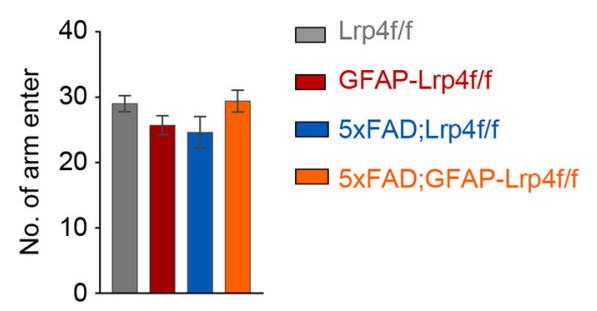

E

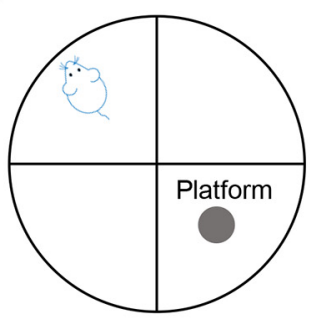

F

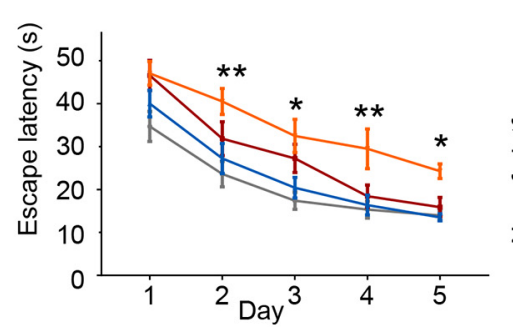

G

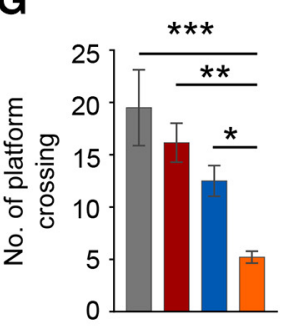

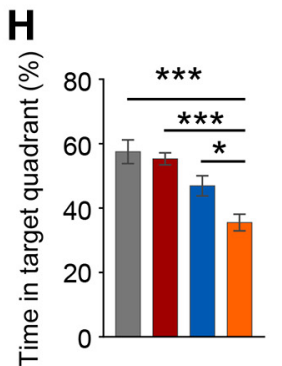

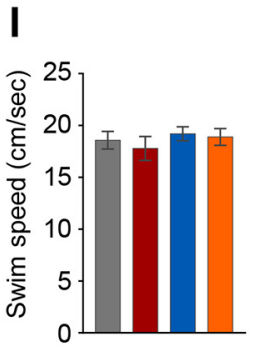

Figure 3. Precipitated cognitive deficits in Lrp4 mutant $5 x$ FAD mice. A, Spatial working memory of Lrp4f/f $(n=13)$, GFAP-Lrp4f/f $(n=10)$, 5xFAD;Lrp4f/f $(n=10)$, and 5xFAD;GFAP-Lrp4f/f $(n=10)$ was assessed by spontaneous alternation in the $Y$ maze. $B, 5 x F A D ; G F A P-L r p 4 f / f$ further reduced the spontaneous alternation compared with $5 x F A D ; L r p 4 f / f$ at 6 months: $F_{(3,39)}=11.21$, $p<0.0001$, ANOVA. $C$, The total distance explored in the $Y$ maze was not different between the four groups: $F_{(3,39)}=0.5198, p=0.6711$, ANOVA. $\boldsymbol{D}$, The total number of arm entries was not different in the four groups: $F_{(3,39)}=1.947, p=0.1380$, ANOVA. $E$, Spatial learning and memory of Lrp4f/f $(n=10)$, GFAP-Lrp4f/f $(n=13), 5 x F A D ; L r p 4 f / f(n=15)$, and 5xFAD;GFAP-Lrp4f/f $(n=12)$ was assessed in water maze. $\boldsymbol{F}$-H, Six-mo 5xFAD;GFAP-Lrp4f/f exhibited increase the latency to the hidden platform $(\boldsymbol{F}), F_{(3,230)}=19.6, p<0.0001$, ANOVA; decrease the number of platform crossing $(\boldsymbol{G}), F_{(3,46)}=8.852, p<0.0001$, ANOVA; reduce the time in the target quadrant $(\boldsymbol{H}), F_{(3,46)}=11.35, p<0.0001$, ANOVA, compared with Lrp4f/f and 5xFAD;Lrp4f/f groups. $\boldsymbol{I}$, Four groups of mice showed similar swim speed in the water maze: $F_{(3,46)}=0.5068, p=0.6795$, ANOVA. Data are mean \pm SEM. ${ }^{*} p<0.05,{ }^{* *} p<0.01,{ }^{* * *} p<0.001$.

A

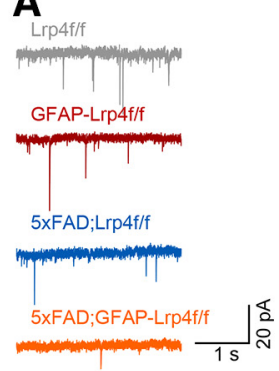

$\mathbf{E}$

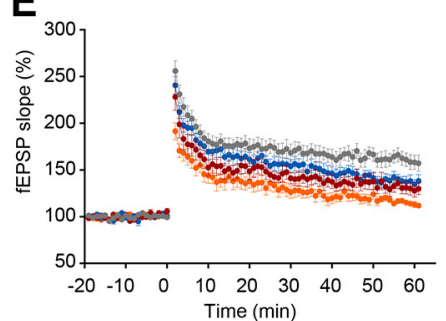

B

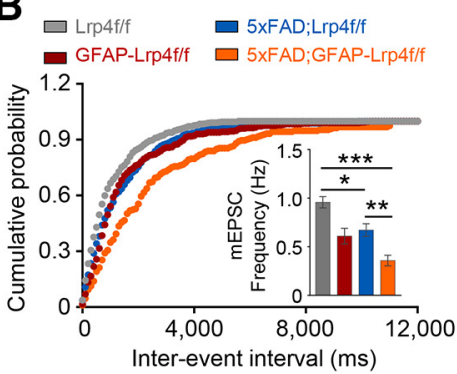

$\mathbf{F}$

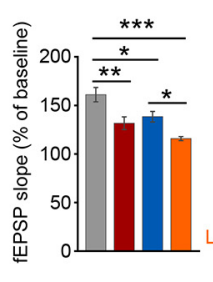

C

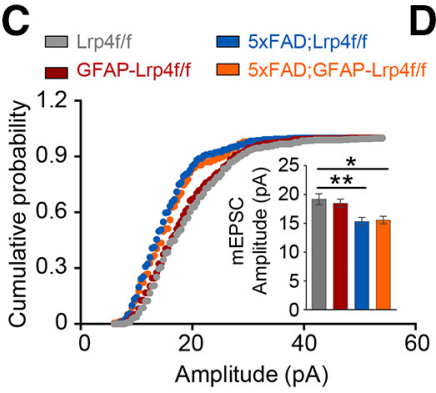

$\mathbf{D}_{\text {Lrp } 4 \mathrm{f} / \mathrm{f}}$

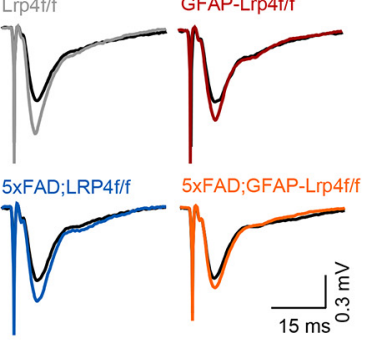

H

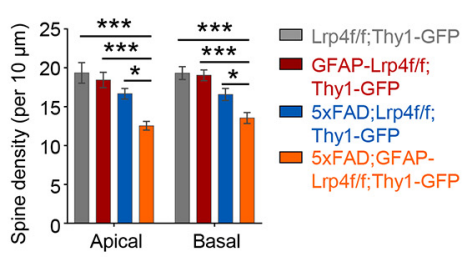

Figure 4. LRP4 deficiency further reduced mEPSC frequency, LTP, and spine density of 6-mo 5xFAD mice. $\boldsymbol{A}$, Representative mEPSC traces. $\boldsymbol{B}$, Cumulative distributions of mEPSC frequency, $F_{(3,31)}=13.59, p<0.0001$, ANOVA. C, Cumulative distributions of mEPSC amplitude. Data are summarized in histograms. Data were from 3 mice of each genotype with 2 or 3 neurons per mouse, $F_{(3,31)}=6.792, p=0.0012$, ANOVA. $\boldsymbol{D}$, Representative fEPSP traces. $\boldsymbol{E}$, The plot of fEPSP slope against time. $\boldsymbol{F}$, Quantitative data in $\boldsymbol{E}$. Shown were potentiation at $50-60$ min after highfrequency stimulation. Data were from 4 mice of each genotype and $>2$ slices per mouse, $F_{(3,29)}=10.41, p<0.0001$, ANOVA. $\boldsymbol{G}$, Representative basal and apical dendritic spine. $\boldsymbol{H}$, Quantitative data. The dendritic spine was collected from 4 mice of each genotype and $>5$ neurons per mouse: apical: $F_{(3,78)}=11.78, p<0.0001$, ANOVA; basal: $F_{(3,81)}=13.33, p<0.0001$, ANOVA. Data are mean \pm SEM. ${ }^{*} p<0.05,{ }^{* *} p<0.01,{ }^{* * *} p<0.001$.

PFC LFPs at theta, beta, and gamma frequencies was reduced in $5 x F A D$ mice, revealing a novel cellular mechanism of AD pathology (Fig. 5A). Importantly, the coherence at theta frequency was further reduced by LRP4 deficiency in $5 x F A D$ mice (Fig. $5 B, C$ ). At delta frequency, although $5 x F A D$ and LRP4 deficiency alone had no effect on the vHPC-PFC coherence, the dramatic reduction was observed in the $5 x F A D ; G F A P-L r p 4 f / f$ mice. These results demonstrate that the hippocampal-PFC connectivity is compromised in $5 x F A D$ mice, and such deficits are augmented by LRP4 deficiency (Fig. 5B,C). 
A

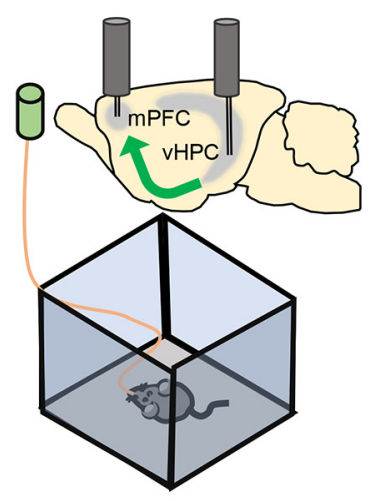

B

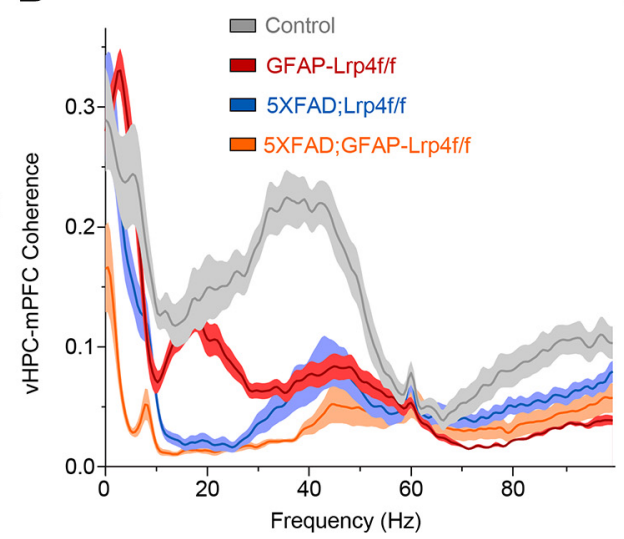

C

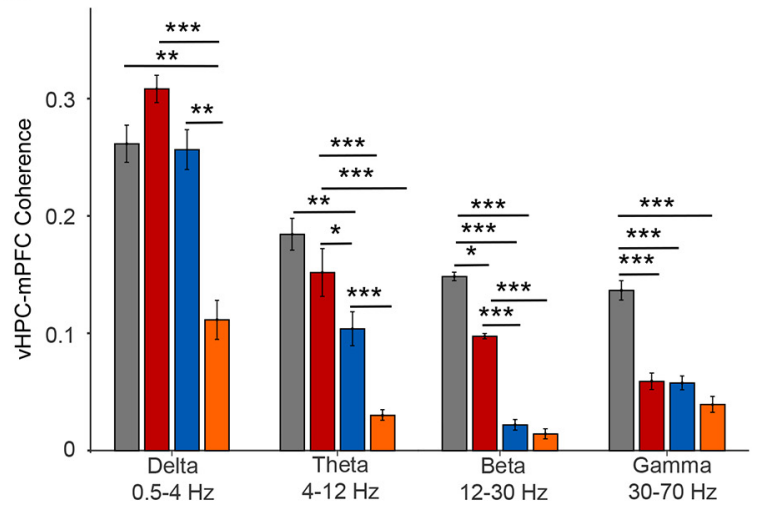

Figure 5. A further disconnect of the vHPC-PFC by Lrp4 mutation in 5xFAD mice. A, Schematic diagram of in vivo recording. Two tetrodes were implanted in vHPC and PFC, respectively. LFPs were recorded in free-moving 6-mo mice in an open field. $\boldsymbol{B}$, Coherence between vHPC and PFC LFPs of $\operatorname{Lrp} 4 \mathrm{f} / \mathrm{f}(n=10)$, GFAP-Lrp4f/f $(n=9)$, 5xFAD;Lrp4f/f $(n=14)$, and 5xFDA;GFAPLrp4f/f $(n=11)$ mice. $C$, vHPC-PFC synchrony at different frequencies: Delta, $F_{(3,40)}=8.389, p=0.0002$, ANOVA; Theta, $F_{(3,40)}=14.84, p<0.0001$, ANOVA; Beta, $F_{(3,40)}=35.28, p<0.0001$, ANOVA; Gamma, $F_{(3,40)}=15.76, p<0.0001$, ANOVA. Data are mean \pm SEM. ${ }^{*} p<0.05,{ }^{* *} p<0.01,{ }^{* * *} p<0.001$.

\section{Detection of the $\operatorname{Lrp} 4$ promoter activity in astrocytes, not pyramidal neurons, oligodendrocytes, or microglia}

What are the mechanisms by which LRP4 regulates AD pathology in $5 x F A D$ mice? To answer this question, it is necessary to know where $\operatorname{Lrp} 4$ is expressed. Recently, we demonstrated that Lrp4 is mainly expressed in astrocytes by Lrp4-LacZ reporter mice (Sun et al., 2016), although in vitro data suggest that it may be present in embryonic excitatory neurons (Handara et al., 2019). Because of the lack of reliable anti-LRP4 antibody for immunostaining analysis, we generated a knock-in mouse Lrp4$\mathrm{Cre}^{\text {ERT2 }}$, which expresses 2A-GFP-CreERT2 cassette under the promoter of the endogenous $\operatorname{Lrp} 4$ (Fig. 6A). Lrp4-Cre ${ }^{\text {ERT2 }}$ mice were crossed with tdTomato reporter mice (Ai9), and then the compound mice were treated with tamoxifen (Tam) $(100 \mathrm{mg} / \mathrm{kg})$ at P42 every other day three times (Fig. 6B). As shown in Figure $6 C-F$, the tdTomato-labeled cells were distributed across the cortex and hippocampus and in areas where astrocytes are known to be enriched, such as stratum lacunosum-moleculare (Fig. $6 F$ ).

To further study the identity of these tdTomato ${ }^{+}$cells, we also cross the Lrp4-Cre ${ }^{\mathrm{ERT}}$; $\mathrm{Ai} 9$ mice with $\mathrm{Tg}$ (Slcla2-EGFP) mice, which is labeling the astrocyte (Gong et al., 2003). We found that most of the tdTomato ${ }^{+}$cells colabeled with the GFP-positive cell (Fig. 6G, $H$ ). The coimmunostaining study indicated that tdTomato $^{+}$cells could be labeled by astrocyte markers, including Aldoc and $\mathrm{S} 100 \beta$, but not by neuronal marker NeuN, oligodendrocyte marker Oligo2, or microglia/macrophage marker Ibal (Fig. 6G,H). Together, these results demonstrate that $\operatorname{Lrp} 4$ is mainly expressed in astrocytes, little in neurons, oligodendrocytes, or microglia.

\section{Astrocyte-specific Lrp4 KO augmented A $\beta$ load in 5xFAD mice}

Knowing that $\operatorname{Lrp} 4$ is expressed in astrocytes, we next determined whether astrocytic LRP4 regulates A $\beta$ deposition. Human GFAPCreERT2 mice express CreERT2 by a $2 \mathrm{~kb}$ minimal promoter of the human GFAP gene (Casper et al., 2007). We and others have shown that CreERT2 is expressed in astrocytes on Tam induction (Casper et al., 2007; Sun et al., 2016). We generated GFAPCreERT2;Lrp4f/f (referred to as iGFAP-Lrp4f/f) mice to specifically delete Lrp4 in astrocytes (Sun et al., 2016), which were crossed with $5 \mathrm{xFAD}$ to produce 5xFAD;iGFAP-Lrp4f/f compound mice. Tamoxifen was injected at 1.5 months $(100 \mathrm{mg} / \mathrm{kg}$, i.p., once every other day, 3 times) and mice were killed at 7 months. LRP4 protein levels were reduced to $\sim 20 \%$ in the whole-brain lysate of Tamtreated 5xFAD;iGFAP-Lrp4f/f mice, compared with Tam-treated 5xFAD;Lrp4f/f mice (Fig. 7A,B). Remarkably, $\mathrm{A} \beta$ deposition was higher in Tam-treated 5xFAD;iGFAP-Lrp4f/f mice, compared with Tam-treated 5xFAD;Lrp4f/f mice (Fig. 7C,D).

In addition, to examine whether neuronal LRP4 has an effect on A $\beta$ deposition, we generated neuron-specific Lrp4 KO mice by crossing $5 x F A D ; L r p 4 f / f$ mice with Neurod6-Cre mice where Cre is expressed under the promoter of the gene of Neurod6 (Goebbels et al., 2006). Resulting Neurod6-Cre; Lrp4f/f;5xFAD (referred to as 5xFAD;Neurod6-Lrp4f/f) had similar LRP4 protein level in the whole-brain lysates, compared with $5 x F A D ; L r p 4 f / f$ mice (Fig. $7 E, F$ ). These results agree with the notion that $L r p 4$ is mainly expressed in astrocytes, not neurons (Fig. 6) (Sun et al., 2016). Importantly, little changes in $\mathrm{A} \beta$ deposition was noticed in the cortex and hippocampus between $5 x F A D$; Lrp4f/f and $5 x F A D$;Neurod6Lrp4f/f mice (Fig. 7G,H). Together, these results demonstrate that astrocytic LRP4 deficiency enhances $\mathrm{A} \beta$ deposition in $5 x F A D$ mice.

\section{Compromised A $\beta 42$ uptake by Lrp4-deficient astrocytes}

To investigate how Lrp4 mutation increases A $\beta$ plaque formation, we first examined mRNA levels of $A p p$ and various risk genes that may alter $\mathrm{A} \beta$ metabolism, including Bace1, Bace2, Psen1, and Psen2. We also assessed the impact of LRP4 deficiency on the expression of human APP and PSEN1 genes in $5 \mathrm{xFAD}$ mice. mRNA levels of mouse genes, as well as human genes, were similar between 5xFAD;GFAP-Lrp4f/f hippocampus and 5xFAD;Lrp4f/f hippocampus (Fig. 8A), excluding an effect of LRP4 deficiency on genes transcription. Next, we determined levels of APP and its degradation peptides CTF $\alpha$ and CTF $\beta$. CTF $\alpha$ and CTF $\beta$ were detected by 8717 , a polyclonal antibody that specifically recognizes the C-terminal of APP where CTF $\beta$ was detected by $6 \mathrm{E} 10$, a monoclonal antibody that specifically recognizes the N-terminal 1-16 amino acid residues of $\mathrm{A} \beta$ (Fig. $8 B$ ) (Wen et al., 2011). We found that APP (Fig. 8C,D), CTF $\beta$ (Fig. $8 C, E$ ), and CTF $\alpha$ (Fig. $8 C, F$ ) were not changed in the cortex and hippocampus between $5 x F A D ; G F A P-L r p 4 f / f$ and $5 x F A D$; Lrp4f/f mice. Together, these results indicate that the deletion of Lrp4 does not change A $\beta$ production in the cortex and hippocampus. 
A

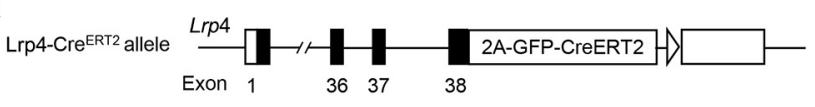

C

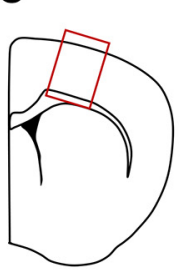

D

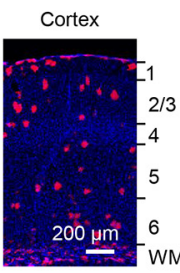

D E

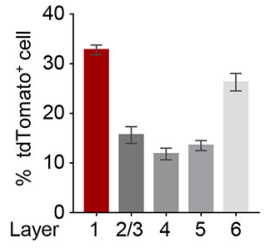

B

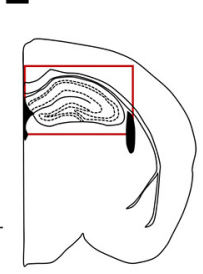

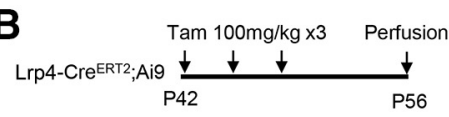

P56

\section{G}
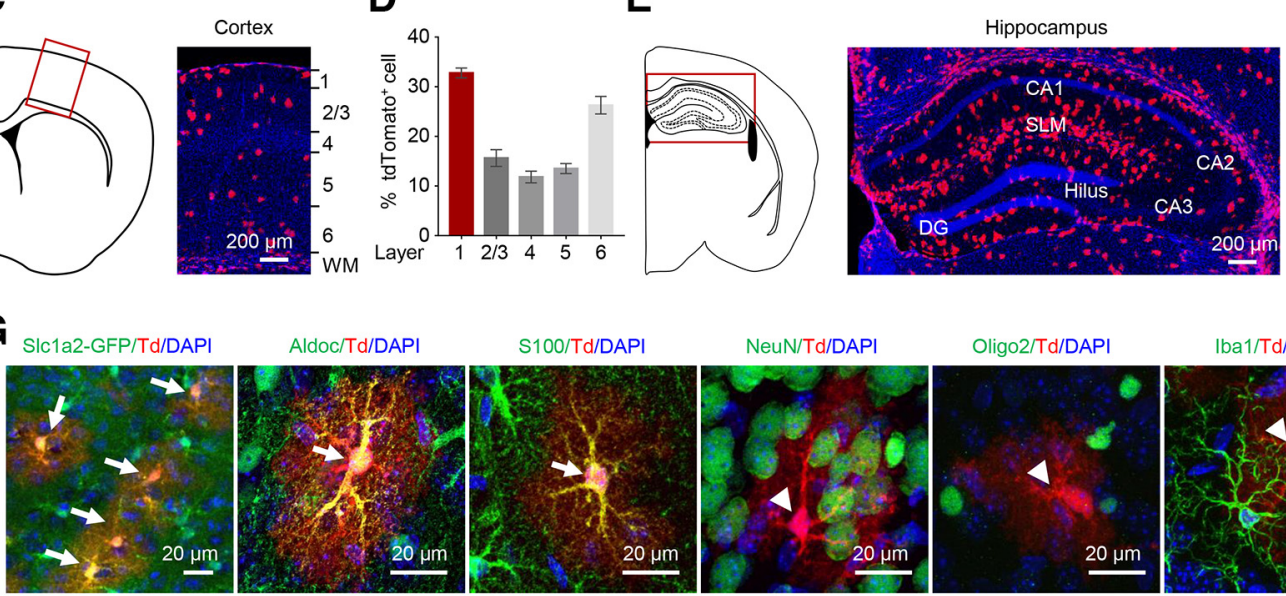

F

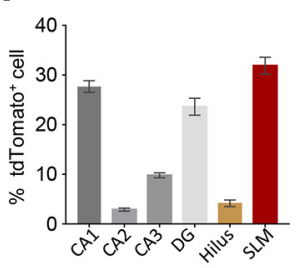

Figure 6. Lrp4 is mainly expressed in astrocytes, not neurons, oligodendrocytes, or microglia. $\boldsymbol{A}$, Knock-in of the $2 A$-CreERT2 cassette in exon 38 of the $L r p 4$ allele. $\boldsymbol{B}$, The protocol of Tam administration. Lrp4-CreERT2;Ai9 mice at P42 were treated with Tam (100 mg/kg, i.p., three times, once every other day) and killed at P56. Shown are brain sections of the cortex (C,D), hippocampus $(\boldsymbol{E}, \boldsymbol{F})$, and enlarged views of cortical cells costained with the different maker $(\boldsymbol{G})$, except that the Slc1a2 ${ }^{+}$cells are labeled by SIc1a2-GFP (in Slc1a2-GFP; Lrp4-CreERT2;Ai9 mice). tdTomato $^{+}$cell costained with astrocytes marker Aldoc and $\mathrm{S} 100 \beta$ (arrow), but not the with NeuN, 0ligo2, and Iba1 (arrowhead). Scale bar, $20 \mu \mathrm{m}$. $\boldsymbol{H}$, Quantification of double-positive cells. $n=3$ for each group. Td, tdTomato. Data are mean \pm SEM.

A

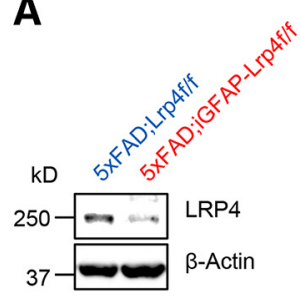

$\mathbf{E}$

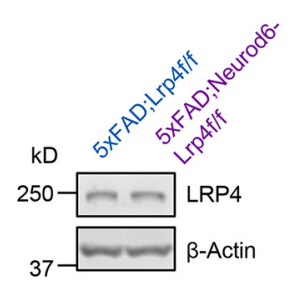

B

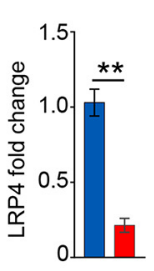

$\mathbf{F}$

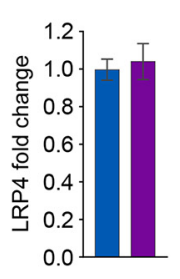

C

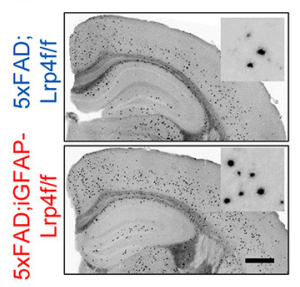

G

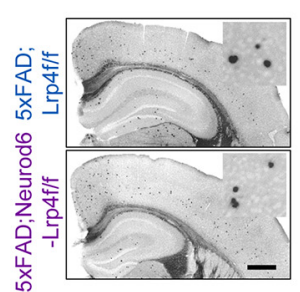

D

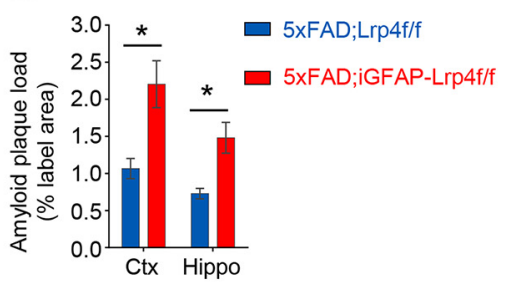

H

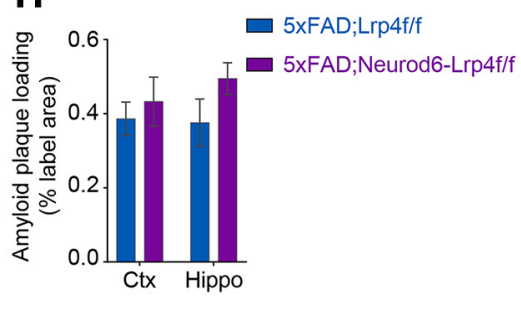

Figure 7. Augmented A $\beta$ deposition in astrocyte-specific Lrp4 K0 5xFAD mice. $\boldsymbol{A}, \boldsymbol{B}$, LRP4 protein was reduced in the brain of Tam-treated 5xFAD;iGFAP-Lrp4f/f mice, compared with Tamtreated 5xFAD;Lrp4f/f mice. Representative images $(\boldsymbol{A})$ and quantification $(\boldsymbol{B}) . n=3$ for each group, $t_{(4)}=8.121, p=0.0013$, unpaired $t$ test. $\boldsymbol{C}, \boldsymbol{D}$, Increase of $A \beta$ deposition in Tam-treated 5XFAD;iGFAP-Lrp4f/f mice, compared with Tam-treated 5xFAD;Lrp4f/f mice at 7 months. Representative images $(\boldsymbol{C})$ and quantification (D). Scale bar: $\boldsymbol{C}, 500 \mu \mathrm{m}$. $n=4$ for each group: (tx, $t_{(6)}=3.312, p=0.0162$, unpaired $t$ test; Hippo, $t_{(6)}=3.433, p=0.0139$, unpaired $t$ test. $\boldsymbol{E}, \boldsymbol{F}$, LRP4 protein level is similar between 5xFAD;Lrp4f/f and 5xFAD;Neurod6-Lrp4f/f brain. Representative images $(\boldsymbol{E})$ and quantification $(\boldsymbol{F}) . n=3$ for each group, $t_{(4)}=0.5513, p=0.6108$, unpaired $t$ test. $\boldsymbol{G}$, $\boldsymbol{H}$, Similar A $\beta$ deposition in 5xFAD;Lrp4f/f and 5xFAD;Neurod6-Lrp4f/f mice at 6 months. Representative images $(\boldsymbol{G})$ and quantification $(\boldsymbol{H})$. Scale bar. $\boldsymbol{G}, 500 \mu \mathrm{m}$. $n=3$ for each group: $\left(\mathrm{tx}, t_{(4)}=0.5835, p=0.5909\right.$, unpaired $t$ test; Hippo, $t_{(4)}=1.546$, $p=0.1971$, unpaired $t$ test. Data are mean \pm SEM. ${ }^{*} p<0.05,{ }^{* *} p<0.001$.

Astrocytes can uptake oligomer and fibrillary $\mathrm{A} \beta 42$ in vitro and in vivo, which contributes to $\mathrm{A} \beta$ clearance and prevents the detrimental effect of $\mathrm{A} \beta$ accumulation in $\mathrm{AD}$ (Wyss-Coray et al., 2003; Koistinaho et al., 2004). Therefore, we next examined whether Lrp4 deletion in astrocytes affects cellular $\mathrm{A} \beta$ uptake. Primary astrocytes were incubated with $500 \mathrm{~nm}$ FAM-labeled $\mathrm{A} \beta 42$ for $2 \mathrm{~h}$ at $37^{\circ} \mathrm{C}$ and immunostained with an antibody against GFAP. As shown in Figure 9B, FAM-A $\beta 42$ in GFAPLrp $4 \mathrm{f} / \mathrm{f}$ astrocytes was reduced, compared with Lrp $4 \mathrm{f} / \mathrm{f}$ astrocytes
(Fig. $9 A-C$ ), suggesting that LRP4 deficiency may reduce $\mathrm{A} \beta$ uptake. To further test this hypothesis, we analyzed cell-associated FAM-A $\beta 42$ by FACS. As shown in Figure $9 D$, FAMA $\beta 42$-associated cell numbers were reduced in Lrp4-deficient astrocytes, compared with controls (Fig. 9D), suggesting deficient A $\beta$ uptake in $\operatorname{Lrp} 4$ mutant astrocytes. Finally, we measured oligomeric $A \beta 42$ in media of astrocytes after the $48 \mathrm{~h}$ incubation (Fig. 9E). A $\beta 42$ levels were higher in the media of $L r p 4$ mutant astrocytes, compared with control astrocytes (Fig. 9F). These 
A

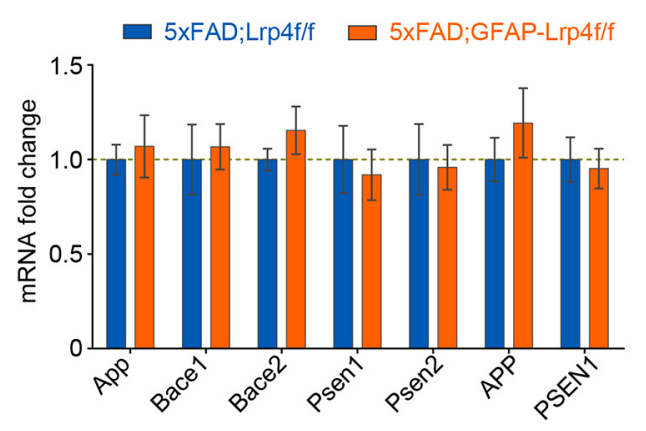

B
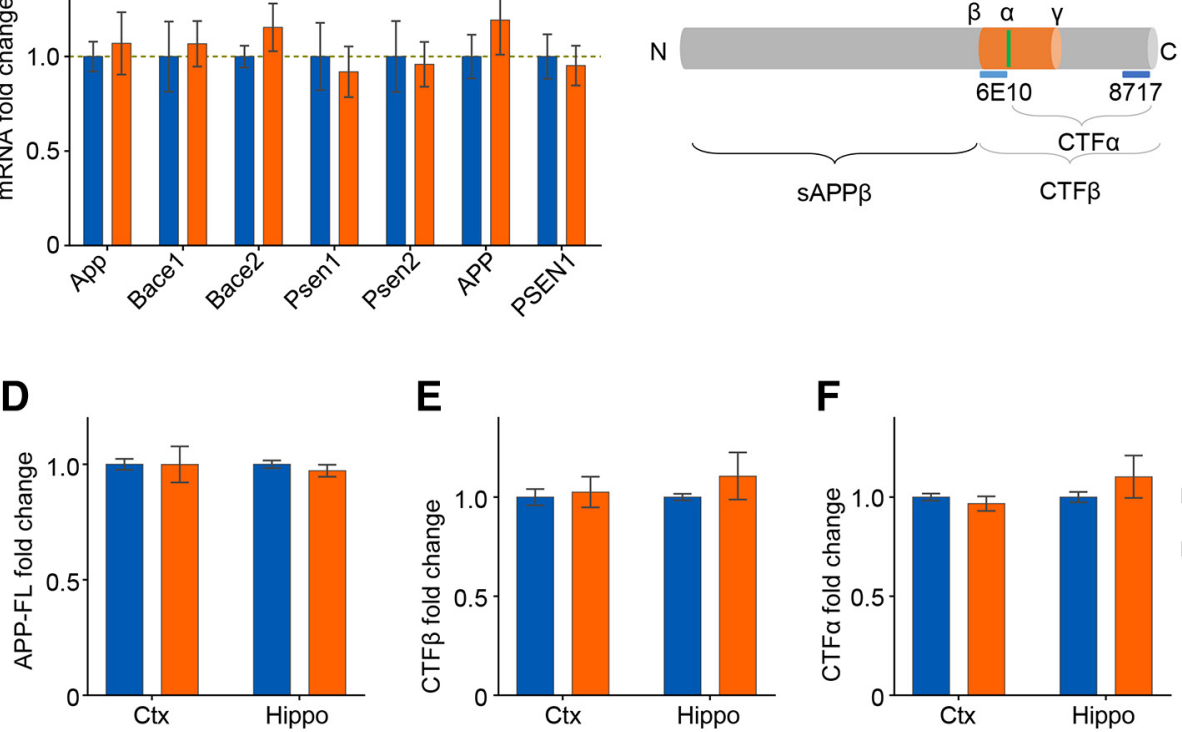

E

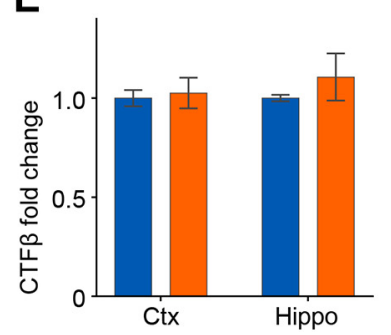

$\mathbf{F}$

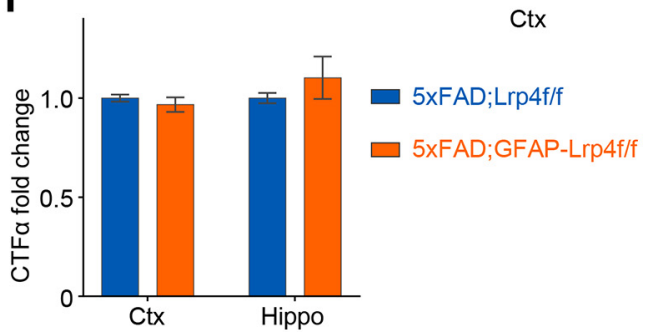

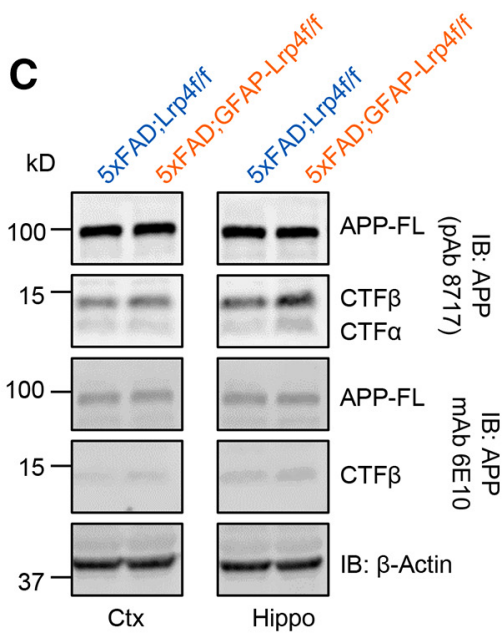

Figure 8. No effect on $A \beta$ production by $L r p 4$ mutation in $5 x F A D$ mice. $A$, qPCR analysis of $A p p$ and genes involved in its processing in 5xFAD;Lrp4f/f and $5 x F A D ; G F A P-L r p 4 f / f$ mice at 1.5 months in the hippocampus. $n=3$ for each group: App, $t_{(4)}=0.3824, p=0.7216 ;$ Bace $1, t_{(4)}=0.3053, p=0.7754 ;$ Bace2, $t_{(4)}=1.109, p=0.3296 ; P_{\text {sen }}, t_{(4)}=0.3639, p=0.7343 ;$ Psen2, $t_{(4)}=0.1852, p=0.8621 ; A P P, t_{(4)}=0.8909, p=0.4233 ;$ PSEN1, $t_{(4)}=0.3018, p=0.7778$, unpaired $t$ test. $\boldsymbol{B}$, Illustration of human APP structure and its cleavage sites. The indication of the epitopes for the antibodies $6 \mathrm{E} 10$ and 8717 and the cleavage fragments (TF $\beta$ and CTF $\alpha$. C, Western blot analysis of APP-FL, $\beta$ CTF, and $\alpha$ TFF levels using the indicated antibodies. Homogenates of cortex and hippocampus from 5xFAD;Lrp4f/f and 5xFAD;GFAP-Lrp4f/f mice at 1.5 months of age were subjected to Western blot. $n=3$ for each group. Three independent replicated experiments were performed. $\boldsymbol{D}$, Quantification of APP-FL: $\mathrm{Ctx}, t_{(4)}=0.0061, p=0.9954$; Hippo, $t_{(4)}=0.9009, p=0.4186$, unpaired $t$ test. $\boldsymbol{E}$, Quantification of cleavage products $\beta$ CTF: $\left(\mathrm{tx}, t_{(4)}=0.2929, p=0.7842\right.$; Hippo, $t_{(4)}=0.8861, p=0.4256$, unpaired $t$ test. $\boldsymbol{F}$, Quantification of cleavage products $\alpha \mathrm{CTF}$ : $\mathrm{Ctx}_{1} t_{(4)}=0.8065, p=0.4652 ;$ Hippo, $t_{(4)}=0.9339$, $p=0.4032$, unpaired $t$ test. Data are mean \pm SEM. ${ }^{*} p<0.05$.

results indicate that LRP4 deficiency impairs uptake of $\mathrm{A} \beta 42$ by astrocytes.

Members of the LDLR family, in particular, LDLR and LRP1, have been shown to interact with ApoE and thus promote $\mathrm{A} \beta$ clearance. We determined whether LRP4 was able to interact with ApoE and, if so, whether the interaction varies among different alleles. ApoE protein was produced by astrocyte lines that express different alleles of human ApoE. We found that LRP4 interaction with ApoE3 was better than that with ApoE4 (Fig. $9 G, H)$. Together, these results support a working model where LRP4 in astrocytes promotes $\mathrm{A} \beta$ uptake by serving as a receptor for ApoE.

\section{Discussion}

$\mathrm{A} \beta$ clearance is regulated by LDLR family members in particular LDLR and LRP1 (LDLR-related protein 1) (Lane-Donovan et al., 2014; Lane-Donovan and Herz, 2017). Lack of Ldlr aggravates $\mathrm{A} \beta$ deposits in $\mathrm{AD}$ transgenic mice (Cao et al., 2006), whereas $L d l r$ overexpression reduces $\mathrm{A} \beta$ deposition and increases $\mathrm{A} \beta$ clearance (J. Kim et al., 2009). Mutation of RAP (receptor-associated protein), an antagonist of the LDLR family, increases $A \beta$ deposit (Van Uden et al., 2002). Astrocytic A $\beta$ uptake could be blocked by astrocyte-specific KO of $L d l r$ and $\operatorname{Lrp} 1$ (Koistinaho et al., 2004; Basak et al., 2012; C. C. Liu et al., 2017). Considering the abundance of astrocytes in the brain and their modulatory functions on multiple brain cells, they may represent a major mechanism for A $\beta$ clearance. Here, we demonstrated that astrocytic LRP4 serves as a receptor for ApoE to uptake A $\beta$ for degradation in a mouse model of amyloid. Genetically, deletion Lrp4 in astrocytes in 5xFAD mice exacerbated amyloid pathology. In vitro, primary culture astrocytes demonstrated that this effect due to without LRP4 in astrocyte impairing the astrocytic LRP4-mediated $\mathrm{A} \beta$ uptake and degradation. Receptor-mediated astrocyte clearance is an efficient way of reducing brain $\mathrm{A} \beta$, due to internalizing by the ApoE receptor are delivered to lysosomes for degradation and the abundance of astrocytes (De Strooper and Karran, 2016; Yamazaki et al., 2019). Together with reduced levels of LRP4 in the brain of $\mathrm{AD}$ patients, these observations suggest a new pathologic mechanism of $\mathrm{AD}$ development.

LRP4 has a large ECD consisting of an LDLa domain and four $\beta$ propeller domains that is capable of interacting with various proteins, including ApoE and agrin (Herz and Bock, 2002; May and Herz, 2003; Shen et al., 2015). Loss of LRP4 function in astrocytes impairs $\mathrm{A} \beta$ uptake may due to insufficient receptors for ApoE. ApoE is present in the amyloid plaque (Rebeck et al., 1993; Strittmatter et al., 1993a) and binds to A $\beta$ via the C-terminus, which is also responsible for lipid binding (Strittmatter et al., 1993b; Tamamizu-Kato et al., 2008). LRP4 could interact with ApoE in vivo (Lu et al., 2007). Astrocyte-mediated degradation of $\mathrm{A} \beta$ occurs through a mechanism that depends on both ApoE and LRP1 (Koistinaho et al., 2004). In accord, Ldlr downregulation reduced $\mathrm{A} \beta$ uptake, whereas the upregulation enhanced both the uptake and clearance of $\mathrm{A} \beta$ in astrocytes (Basak et al., 2012). Because of the interaction between ApoE and $\mathrm{A} \beta$ occurs under physiological conditions, ApoE may be required for astrocyte clearance of $\mathrm{A} \beta$ (Verghese et al., 2013). ApoE isoforms have different binding affinities for $\mathrm{A} \beta$, with ApoE3 with higher affinity than ApoE4, for example ( $\mathrm{LaDu}$ et al., 1994). On the other hand, ApoE4 could impair A $\beta$ clearance 
A

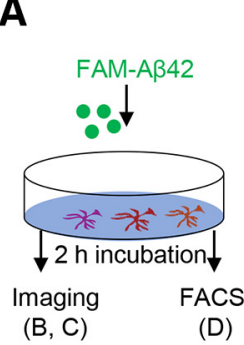

E

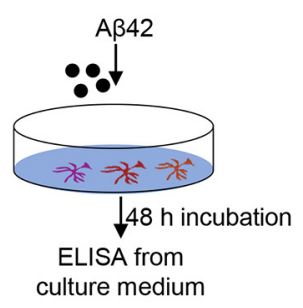

B

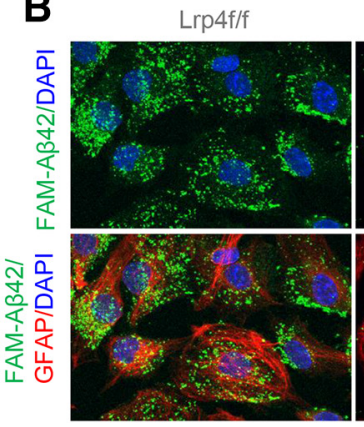

F

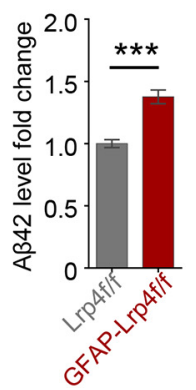

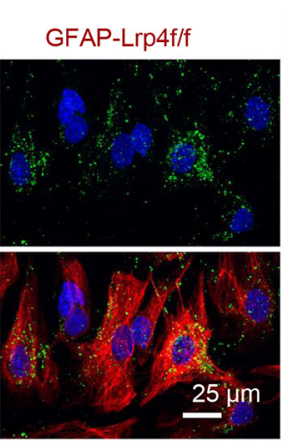

G

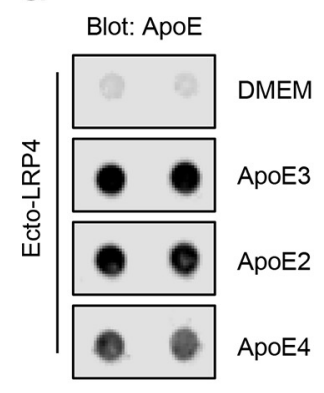

D

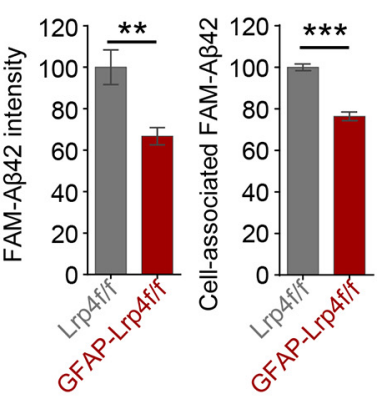

H

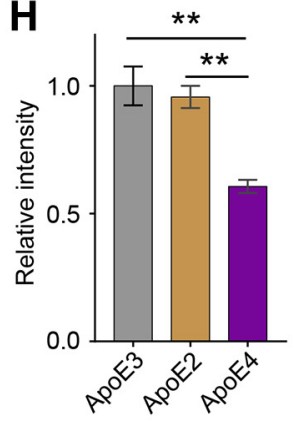

Figure 9. Impaired $A \beta$ uptake in Lrp4 mutated primary astrocytes. $A$, Experimental design. Primary astrocytes derived from P3 Lrp4f/f and GFAP-Lrp4f/f mice brain were incubated with FAM-A $\beta 42$ for imaging (B) and FACS (D). B, Reduced FAM-A $\beta 42$ intensity in astrocytes. Scale bar, $25 \mu \mathrm{m}$. C, Quantitative analysis of data in $\boldsymbol{B}$. $n=8$ for Lrp4f/f, $n=6$ for GFAP-Lrp4f/f, $t_{(12)}=3.212, p=0.0075$, unpaired $t$ test. $D$, Decreased cell-associated $A \beta 42$ in astrocyte-derived from GFAP-Lrp4f/f mice compared with astrocyte-derived from Lrp4f/f mice by FACS. $n=4$ for each group, $t_{(6)}=8.869, p=0.0001$, unpaired $t$ test. $E, F$, Increased $A \beta 42$ level in the Lrp4 mutant astrocyte medium compared with Lrp4f/f astrocytes medium, $n=8$ for each group, $t_{(14)}=5.887, p<0.0001$, unpaired $t$ test. $\mathbf{G}, \boldsymbol{H}$, Reduced LRP4 interaction with the ApoE4. The nitrocellulose membrane was spotted with $500 \mathrm{ng}$ of Ecto-LRP4 and incubated with different human ApoEs. ApoE was produced by mouse astrocytes that express lipidated and secrete human ApoE isoforms. Bound ApoE was detected using a biotinylated anti-ApoE antibody. Representative dot blots $(\boldsymbol{G})$ and quantitative data $(\boldsymbol{H}), F_{(2,6)}=16.84, p=0.0035$, ANOVA. Data are mean \pm SEM. ${ }^{* *} p<0.01 .{ }^{* *} p<0.0001$.

without altering $\mathrm{A} \beta$ production (Castellano et al., 2011). ApoE3-expressing mice develop fewer A $\beta$ plaques than ApoE4expressing mice (Holtzman et al., 1999, 2000). Human iPSCderived astrocytes homozygous for ApoE4 are impaired in $\mathrm{A} \beta 42$ uptake, compared with ApoE3 controls (Y. T. Lin et al., 2018). Interestingly, LRP4 has a lower affinity for ApoE4 than for ApoE3, consistent with the notion that ApoE4 is less efficient in A $\beta$ clearance.

LRP4 is a receptor for many ligands, including agrin and APP (Herz and Bock, 2002; May and Herz, 2003; Shen et al., 2015). Agrin is expressed in the brain (Ksiazek et al., 2007), in particular, the neuronal isoform, which contains a $\mathrm{B} / \mathrm{Z}^{+}$insert at the C-terminus that is required for binding to LRP4 and MuSK activation (Bezakova and Ruegg, 2003; B. Zhang et al., 2008; Zong et al., 2012). In addition, crystal structural analysis indicates the essential role of $\beta 1$ in LRP4, which is required and sufficient to interact with agrin (W. Zhang et al., 2011). Agrin stimulation activates MuSK in astrocytes in a manner dependent on LRP4 (Sun et al., 2016). Moreover, agrin was shown to interact with $\mathrm{A} \beta$ (Cotman et al., 2000); and agrin mutation increases $\mathrm{A} \beta$ deposition, and overexpression of agrin reduces $\mathrm{A} \beta$ accumulation in APP/PS1 mice (Rauch et al., 2011). Whether $\mathrm{A} \beta$ uptake by astrocytes is regulated by agrin signaling warrants further investigation.

It is worth pointing out that, at the moment, there are no clinic data to link LRP4 to AD. However, LRP4 has been shown to interact with proteins whose genes are strongly associated with AD. For example, it interacts with APP, whose Swedish mutations cause early-onset AD (Haass et al., 1995) and ApoE, whose $\varepsilon 4$ allele is implicated late-onset AD (Corder et al., 1993; Strittmatter et al., 1993a). Both APP's Swedish mutations and ApoE's $\varepsilon 4$ allele are thought to increase AD risk (Hardy and
Selkoe, 2002). APP interaction with LRP4 has been shown to promote agrin signaling, although its role in $\mathrm{AD}$ pathogenesis remains unclear. Here we provide evidence that the LRP4-ApoE interaction is compromised by ApoE4, compared with ApoE3. Members of the LDLR family, in particular LDLR and LRP1, have been shown to interact with ApoE and thus promote $\mathrm{A} \beta$ uptake (Kanekiyo et al., 2014). Because Lrp4 levels are 4- to 10fold higher than those of $L d l r$ and $L r p 1$, we propose that LRP4 may play a key role in $\mathrm{A} \beta$ uptake by astrocytes. Indeed, $\mathrm{A} \beta$ uptake was reduced by $\operatorname{Lrp} 4$-deficient astrocytes. This notion is in agreement with the findings that Lrp4 mutation had little effect on APP expression or processing.

The mechanism for LRP4 reduction in postmortem brains of $\mathrm{AD}$ patients remains unclear. The mRNA of $\operatorname{Lrp} 4$ was in the brain between mice at ages of 2.5 and 24 months are increased (Clarke et al., 2018). Therefore, the reduction likely results from a post-translational mechanism. At the neuromuscular junction, LRP4 reduction in aged mice associates with reduced protein stability (Zhao et al., 2018). In ApoE4-expressing astrocytes, LRP1 surface expression was reduced because of altered endosomal $\mathrm{pH}$ (Prasad and Rao, 2018). We showed recently that LRP4 interacts with PRR (prorenin receptor), an auxiliary protein of v-ATPase that is critical to maintaining lysosomal/endosomal $\mathrm{pH}$ (Xiong et al., 2017). This interaction is required for LRP4 downregulation of PRR in osteoblasts (Xiong et al., 2017). Exactly how the stability of LRP4 is regulated in astrocytes warrants future study.

Pathologic mechanisms of cognitive impairments in Lrp4-deficient 5xFAD mice could be complex. Although Lrp4 expression in pyramidal neurons and microglial cells is minimal, functions of these cells could be altered indirectly by $\operatorname{Lrp} 4$ mutation in astrocytes. Furthermore, the deficits could involve $\mathrm{A} \beta$ - 
dependent as well as -independent mechanisms. Impaired astrocytes, because of LRP4 deficiency, may release cytokines or other molecules to alter the function of pyramidal neurons and microglia, and thus contribute to AD development. Indeed, we showed earlier that LRP4 deficiency increases ATP release and adenosine production in mutant mice (Sun et al., 2016). Purinergic and adenosine signaling has been implicated in $\mathrm{AD}$ pathogenesis. Damaged neurons as well as astrocytes can release ATP in response to $\mathrm{A} \beta$ peptides (Orellana et al., 2011; Riteau et al., 2012; Fiebich et al., 2014). ATP and its metabolite adenosine are key agonists for purinergic receptors $\left(\mathrm{P}_{1}\right.$ and $\left.\mathrm{P}_{2}\right)$ or adenosine receptors $\left(A_{1} R, A_{2 A} R, A_{2 B} R\right.$, and $A_{3} R$ ), respectively (Cieślak and Wojtczak, 2018). $A_{1} R$ at presynaptic terminals mediates adenosine inhibition of glutamate release (Kimura et al., 2003); however, its level is reduced in AD brains (Jaarsma et al., 1991). Interestingly, $A_{2 A} R$ expression is increased in brains of aged animals, AD mice model, and AD patients (Canas et al., 2009; Viana da Silva et al., 2016). $A_{2 A} R$ inhibition or genetic silencing could reduce $\mathrm{A} \beta$ in cultured neurons and protect against learning and memory deficits in $\mathrm{AD}$ animal models or during aging (Canas et al., 2009; Orr et al., 2015, 2018; Viana da Silva et al., 2016). These results suggest the involvement of $\mathrm{A}_{2 \mathrm{~A}} \mathrm{R}$ activation in $\mathrm{AD}$ development. Among $\mathrm{P} 2$ receptors, $\mathrm{P}_{2} \mathrm{X}_{7}$ receptor $\left(\mathrm{P}_{2} \mathrm{X}_{7} \mathrm{R}\right)$ activation plays a role in $\mathrm{AD}$ development. An SNP $(489 \mathrm{C}>\mathrm{T})$ of $P_{2} X_{7} R$ is associated with $\mathrm{AD}$ (Sanz et al., 2014). $\mathrm{P}_{2} \mathrm{X}_{7} \mathrm{R}$ is upregulated in astrocytes and microglia near $\mathrm{A} \beta$ plaques in $\mathrm{AD}$ humans and mice (Martin et al., 2019a,b). Additionally, $\mathrm{P}_{2} \mathrm{X}_{7} \mathrm{R}$ activation is implicated in $\mathrm{AD}$ pathogenesis by promoting superoxide production in microglia (Martin et al., 2019a), activating the NLRP3 inflammasome (Heneka et al., 2013), and participating in $\mathrm{A} \beta$-triggered release of IL- $1 \beta$ from microglia (Rampe et al., 2004; Sanz et al., 2009). Furthermore, pharmacological blockade of $\mathrm{P}_{2} \mathrm{X}_{7} \mathrm{R}$ signaling decreases $\mathrm{A} \beta$ load in $\mathrm{AD}$ mice (Diaz-Hernandez et al., 2012); and $P_{2} X_{7} R$ KO reduces $\mathrm{A} \beta$ lesions, rescues cognitive deficits, and improves synaptic plasticity in AD mice (Martin et al., 2019b). Therefore, increased ATP and adenosine could be a mechanism for enhanced cognitive deficits in $5 x F A D$ mice lacking $\operatorname{Lrp} 4$ by activating relevant receptors in neurons and microglia.

\section{References}

Albert MS, DeKosky ST, Dickson D, Dubois B, Feldman HH, Fox NC, Gamst A, Holtzman DM, Jagust WJ, Petersen RC, Snyder PJ, Carrillo MC, Thies B, Phelps CH (2011) The diagnosis of mild cognitive impairment due to Alzheimer's disease: recommendations from the National Institute on Aging-Alzheimer's Association workgroups on diagnostic guidelines for Alzheimer's disease. Alzheimers Dement $7: 270-279$.

Alzheimer's Association (2019) 2019 Alzheimer's disease facts and figures. Alzheimers Dement 15:321-387.

Appel JR, Ye S, Tang F, Sun D, Zhang H, Mei L, Xiong WC (2018) Increased microglial activity, impaired adult hippocampal neurogenesis, and depressive-like behavior in microglial VPS35-depleted mice. J Neurosci 38:5949-5968.

Atagi Y, Liu CC, Painter MM, Chen XF, Verbeeck C, Zheng H, Li X, Rademakers R, Kang SS, Xu H, Younkin S, Das P, Fryer JD, Bu G (2015) Apolipoprotein $\mathrm{E}$ is a ligand for triggering receptor expressed on myeloid cells 2 (TREM2). J Biol Chem 290:26043-26050.

Barik A, Lu Y, Sathyamurthy A, Bowman A, Shen C, Li L, Xiong WC, Mei L (2014) LRP4 is critical for neuromuscular junction maintenance. J Neurosci 34:13892-13905.

Basak JM, Verghese PB, Yoon H, Kim J, Holtzman DM (2012) Low-density lipoprotein receptor represents an apolipoprotein E-independent pathway of Abeta uptake and degradation by astrocytes. J Biol Chem 287:13959-13971.

Beffert U, Aumont N, Dea D, Lussier-Cacan S, Davignon J, Poirier J (1999) Apolipoprotein E isoform-specific reduction of extracellular amyloid in neuronal cultures. Brain Res Mol Brain Res 68:181-185.

Bezakova G, Ruegg MA (2003) New insights into the roles of agrin. Nat Rev Mol Cell Biol 4:295-308.

Braak H, Braak E (1991) Neuropathological stageing of Alzheimer-related changes. Acta Neuropathol 82:239-259.

Bussiere T, Bard F, Barbour R, Grajeda H, Guido T, Khan K, Schenk D, Games D, Seubert P, Buttini M (2004) Morphological characterization of Thioflavin-S-positive amyloid plaques in transgenic Alzheimer mice and effect of passive Abeta immunotherapy on their clearance. Am J Pathol 165:987-995.

Canas PM, Porciuncula LO, Cunha GM, Silva CG, Machado NJ, Oliveira JM, Oliveira CR, Cunha RA (2009) Adenosine A2A receptor blockade prevents synaptotoxicity and memory dysfunction caused by beta-amyloid peptides via p38 mitogen-activated protein kinase pathway. J Neurosci 29:14741-14751.

Cao D, Fukuchi K, Wan H, Kim H, Li L (2006) Lack of LDL receptor aggravates learning deficits and amyloid deposits in Alzheimer transgenic mice. Neurobiol Aging 27:1632-1643.

Casper KB, Jones K, McCarthy KD (2007) Characterization of astrocyte-specific conditional knockouts. Genesis 45:292-299.

Castellano JM, Kim J, Stewart FR, Jiang H, DeMattos RB, Patterson BW, Fagan AM, Morris JC, Mawuenyega KG, Cruchaga C, Goate AM, Bales KR, Paul SM, Bateman RJ, Holtzman DM (2011) Human apoE isoforms differentially regulate brain amyloid-beta peptide clearance. Sci Transl Med 3:89ra57.

Chen YJ, Zhang M, Yin DM, Wen L, Ting A, Wang P, Lu YS, Zhu XH, Li SJ, Wu CY, Wang XM, Lai C, Xiong WC, Mei L, Gao TM (2010) ErbB4 in parvalbumin-positive interneurons is critical for neuregulin 1 regulation of long-term potentiation. Proc Natl Acad Sci USA 107:21818-21823.

Chung WS, Clarke LE, Wang GX, Stafford BK, Sher A, Chakraborty C, Joung J, Foo LC, Thompson A, Chen C, Smith SJ, Barres BA (2013) Astrocytes mediate synapse elimination through MEGF10 and MERTK pathways. Nature 504:394-400.

Cieślak M, Wojtczak A (2018) Role of purinergic receptors in the Alzheimer's disease. Purinergic Signal 14:331-344.

Clarke LE, Liddelow SA, Chakraborty C, Munch AE, Heiman M, Barres BA (2018) Normal aging induces A1-like astrocyte reactivity. Proc Natl Acad Sci USA 115:E1896-E1905.

Cohen ML, Kim C, Haldiman T, ElHag M, Mehndiratta P, Pichet T, Lissemore F, Shea M, Cohen Y, Chen W, Blevins J, Appleby BS, Surewicz K, Surewicz WK, Sajatovic M, Tatsuoka C, Zhang S, Mayo P, Butkiewicz M, Haines JL, et al. (2015) Rapidly progressive Alzheimer's disease features distinct structures of amyloid-beta. Brain 138:10091022 .

Corder EH, Saunders AM, Strittmatter WJ, Schmechel DE, Gaskell PC, Small GW, Roses AD, Haines JL, Pericak-Vance MA (1993) Gene dose of apolipoprotein E type 4 allele and the risk of Alzheimer's disease in late onset families. Science 261:921-923.

Cotman SL, Halfter W, Cole GJ (2000) Agrin binds to beta-amyloid (Abeta), accelerates abeta fibril formation, and is localized to Abeta deposits in Alzheimer's disease brain. Mol Cell Neurosci 15:183198.

Crouzin N, Baranger K, Cavalier M, Marchalant Y, Cohen-Solal C, Roman FS, Khrestchatisky M, Rivera S, Féron F, Vignes M (2013) Area-specific alterations of synaptic plasticity in the 5XFAD mouse model of Alzheimer's disease: dissociation between somatosensory cortex and hippocampus. PLoS One 8:e74667.

De Strooper B, Karran E (2016) The cellular phase of Alzheimer's disease. Cell 164:603-615.

Diaz-Hernandez JI, Gomez-Villafuertes R, Leon-Otegui M, HontecillasPrieto L, Del Puerto A, Trejo JL, Lucas JJ, Garrido JJ, Gualix J, MirasPortugal MT, Diaz-Hernandez M (2012) In vivo P2X7 inhibition reduces amyloid plaques in Alzheimer's disease through GSK3beta and secretases. Neurobiol Aging 33:1816-1828.

Feng G, Mellor RH, Bernstein M, Keller-Peck C, Nguyen QT, Wallace M, Nerbonne JM, Lichtman JW, Sanes JR (2000) Imaging neuronal subsets 
in transgenic mice expressing multiple spectral variants of GFP. Neuron 28:41-51.

Fiebich BL, Akter S, Akundi RS (2014) The two-hit hypothesis for neuroinflammation: role of exogenous ATP in modulating inflammation in the brain. Front Cell Neurosci 8:260.

Funato H, Yoshimura M, Yamazaki T, Saido TC, Ito Y, Yokofujita J, Okeda R, Ihara Y (1998) Astrocytes containing amyloid beta-protein (Abeta)positive granules are associated with Abeta40-positive diffuse plaques in the aged human brain. Am J Pathol 152:983-992.

Goebbels S, Bormuth I, Bode U, Hermanson O, Schwab MH, Nave KA (2006) Genetic targeting of principal neurons in neocortex and hippocampus of NEX-Cre mice. Genesis 44:611-621.

Gomez AM, Froemke RC, Burden SJ (2014) Synaptic plasticity and cognitive function are disrupted in the absence of Lrp4. Elife 3:e04287.

Gong S, Zheng C, Doughty ML, Losos K, Didkovsky N, Schambra UB, Nowak NJ, Joyner A, Leblanc G, Hatten ME, Heintz N (2003) A gene expression atlas of the central nervous system based on bacterial artificial chromosomes. Nature 425:917-925.

Haass C, Lemere CA, Capell A, Citron M, Seubert P, Schenk D, Lannfelt L, Selkoe DJ (1995) The Swedish mutation causes early-onset Alzheimer's disease by beta-secretase cleavage within the secretory pathway. Nat Med 1:1291-1296.

Handara G, Hetsch FJ, Juttner R, Schick A, Haupt C, Rathjen FG, Kroger S (2019) The role of agrin, Lrp4 and MuSK during dendritic arborization and synaptogenesis in cultured embryonic CNS neurons. Dev Biol 445:54-67.

Hardy J, Selkoe DJ (2002) The amyloid hypothesis of Alzheimer's disease: progress and problems on the road to therapeutics. Science 297:353-356

Heneka MT, Kummer MP, Stutz A, Delekate A, Schwartz S, VieiraSaecker A, Griep A, Axt D, Remus A, Tzeng TC, Gelpi E, Halle A, Korte M, Latz E, Golenbock DT (2013) NLRP3 is activated in Alzheimer's disease and contributes to pathology in APP/PS1 mice. Nature 493:674-678.

Herz J, Bock HH (2002) Lipoprotein receptors in the nervous system. Annu Rev Biochem 71:405-434.

Holtzman DM, Herz J, Bu G (2012) Apolipoprotein E and apolipoprotein E receptors: normal biology and roles in Alzheimer disease. Cold Spring Harb Perspect Med 2:a006312.

Holtzman DM, Bales KR, Wu S, Bhat P, Parsadanian M, Fagan AM, Chang LK, Sun Y, Paul SM (1999) Expression of human apolipoprotein E reduces amyloid-beta deposition in a mouse model of Alzheimer's disease. J Clin Invest 103:R15-R21.

Holtzman DM, Bales KR, Tenkova T, Fagan AM, Parsadanian M, Sartorius LJ, Mackey B, Olney J, McKeel D, Wozniak D, Paul SM (2000) Apolipoprotein $\mathrm{E}$ isoform-dependent amyloid deposition and neuritic degeneration in a mouse model of Alzheimer's disease. Proc Natl Acad Sci USA 97:2892-2897.

Hu X, Das B, Hou H, He W, Yan R (2018) BACE1 deletion in the adult mouse reverses preformed amyloid deposition and improves cognitive functions. J Exp Med 215:927-940.

Iram T, Trudler D, Kain D, Kanner S, Galron R, Vassar R, Barzilai A, Blinder P, Fishelson Z, Frenkel D (2016) Astrocytes from old Alzheimer's disease mice are impaired in Abeta uptake and in neuroprotection. Neurobiol Dis 96:84-94.

Jaarsma D, Sebens JB, Korf J (1991) Reduction of adenosine A1-receptors in the perforant pathway terminal zone in Alzheimer hippocampus. Neurosci Lett 121:111-114.

Jay TM, Glowinski J, Thierry AM (1989) Selectivity of the hippocampal projection to the prelimbic area of the prefrontal cortex in the rat. Brain Res 505:337-340.

Jiang Q, Lee CY, Mandrekar S, Wilkinson B, Cramer P, Zelcer N, Mann K, Lamb B, Willson TM, Collins JL, Richardson JC, Smith JD, Comery TA, Riddell D, Holtzman DM, Tontonoz P, Landreth GE (2008) ApoE promotes the proteolytic degradation of Abeta. Neuron 58:681-693.

Jones RS, Minogue AM, Connor TJ, Lynch MA (2013) Amyloid-betainduced astrocytic phagocytosis is mediated by CD36, CD47 and RAGE. J Neuroimmune Pharmacol 8:301-311.

Kanekiyo T, Xu H, Bu G (2014) ApoE and Abeta in Alzheimer's disease: accidental encounters or partners? Neuron 81:740-754.
Kanekiyo T, Cirrito JR, Liu CC, Shinohara M, Li J, Schuler DR, Shinohara M, Holtzman DM, Bu G (2013) Neuronal clearance of amyloid-beta by endocytic receptor LRP1. J Neurosci 33:19276-19283.

Khachaturian ZS (1985) Diagnosis of Alzheimer's disease. Arch Neurol 42:1097-1105.

Kim J, Castellano JM, Jiang H, Basak JM, Parsadanian M, Pham V, Mason SM, Paul SM, Holtzman DM (2009) Overexpression of lowdensity lipoprotein receptor in the brain markedly inhibits amyloid deposition and increases extracellular A beta clearance. Neuron 64:632-644.

Kim N, Stiegler AL, Cameron TO, Hallock PT, Gomez AM, Huang JH, Hubbard SR, Dustin ML, Burden SJ (2008) Lrp4 is a receptor for Agrin and forms a complex with MuSK. Cell 135:334-342.

Kimura M, Saitoh N, Takahashi T (2003) Adenosine A(1) receptor-mediated presynaptic inhibition at the calyx of Held of immature rats. J Physiol 553:415-426.

Kimura R, Ohno M (2009) Impairments in remote memory stabilization precede hippocampal synaptic and cognitive failures in 5XFAD Alzheimer mouse model. Neurobiol Dis 33:229-235.

Koistinaho M, Lin S, Wu X, Esterman M, Koger D, Hanson J, Higgs R, Liu F, Malkani S, Bales KR, Paul SM (2004) Apolipoprotein E promotes astrocyte colocalization and degradation of deposited amyloid-beta peptides. Nat Med 10:719-726.

Kounnas MZ, Moir RD, Rebeck GW, Bush AI, Argraves WS, Tanzi RE, Hyman BT, Strickland DK (1995) LDL receptor-related protein, a multifunctional ApoE receptor, binds secreted beta-amyloid precursor protein and mediates its degradation. Cell 82:331-340.

Ksiazek I, Burkhardt C, Lin S, Seddik R, Maj M, Bezakova G, Jucker M, Arber S, Caroni P, Sanes JR, Bettler B, Ruegg MA (2007) Synapse loss in cortex of agrin-deficient mice after genetic rescue of perinatal death. J Neurosci 27:7183-7195.

LaDu MJ, Falduto MT, Manelli AM, Reardon CA, Getz GS, Frail DE (1994) Isoform-specific binding of apolipoprotein $\mathrm{E}$ to beta-amyloid. J Biol Chem 269:23403-23406.

Lane-Donovan C, Herz J (2017) ApoE, ApoE receptors, and the synapse in Alzheimer's disease. Trends Endocrinol Metab 28:273-284.

Lane-Donovan C, Philips GT, Herz J (2014) More than cholesterol transporters: lipoprotein receptors in CNS function and neurodegeneration. Neuron 83:771-787.

Lee CY, Tse W, Smith JD, Landreth GE (2012) Apolipoprotein E promotes beta-amyloid trafficking and degradation by modulating microglial cholesterol levels. J Biol Chem 287:2032-2044.

Lin L, Chen G, Xie K, Zaia KA, Zhang S, Tsien JZ (2006) Large-scale neural ensemble recording in the brains of freely behaving mice. J Neurosci Methods 155:28-38

Lin YT, Seo J, Gao F, Feldman HM, Wen HL, Penney J, Cam HP, Gjoneska E, Raja WK, Cheng J, Rueda R, Kritskiy O, Abdurrob F, Peng Z, Milo B, Yu CJ, Elmsaouri S, Dey D, Ko T, Yankner BA, et al. (2018) APOE4 causes widespread molecular and cellular alterations associated with Alzheimer's disease phenotypes in human iPSC-derived brain cell types. Neuron 98:1294.

Liu CC, Hu J, Zhao N, Wang J, Wang N, Cirrito JR, Kanekiyo T, Holtzman DM, Bu G (2017) Astrocytic LRP1 mediates brain Abeta clearance and impacts amyloid deposition. J Neurosci 37:4023-4031.

Liu RX, Huang C, Bennett DA, Li H, Wang R (2016) The characteristics of astrocyte on Abeta clearance altered in Alzheimer's disease were reversed by anti-inflammatory agent (+)-2-(1-hydroxyl-4-oxocyclohexyl) ethyl caffeate. Am J Transl Res 8:4082-4094.

Lu Y, Tian QB, Endo S, Suzuki T (2007) A role for LRP4 in neuronal cell viability is related to apoE-binding. Brain Res 1177:19-28.

Madisen L, Zwingman TA, Sunkin SM, Oh SW, Zariwala HA, Gu H, Ng LL, Palmiter RD, Hawrylycz MJ, Jones AR, Lein ES, Zeng H (2010) A robust and high-throughput Cre reporting and characterization system for the whole mouse brain. Nat Neurosci 13:133-140.

Malenka RC, Bear MF (2004) LTP and LTD: an embarrassment of riches. Neuron 44:5-21.

Martin E, Amar M, Dalle C, Youssef I, Boucher C, Le Duigou C, Brückner M, Prigent A, Sazdovitch V, Halle A, Kanellopoulos JM, Fontaine B, Delatour B, Delarasse C (2019a) Expression of P2X7R mRNA in mouse astrocytes and microglia. Mol Psychiatry 24:1.

Martin E, Amar M, Dalle C, Youssef I, Boucher C, Le Duigou C, Bruckner M, Prigent A, Sazdovitch V, Halle A, Kanellopoulos JM, Fontaine B, 
Delatour B, Delarasse C (2019b) New role of P2X7 receptor in an Alzheimer's disease mouse model. Mol Psychiatry 24:108-125.

May P, Herz J (2003) LDL receptor-related proteins in neurodevelopment. Traffic 4:291-301.

Morikawa M, Fryer JD, Sullivan PM, Christopher EA, Wahrle SE, DeMattos RB, O’Dell MA, Fagan AM, Lashuel HA, Walz T, Asai K, Holtzman DM (2005) Production and characterization of astrocyte-derived human apolipoprotein $\mathrm{E}$ isoforms from immortalized astrocytes and their interactions with amyloid-beta. Neurobiol Dis 19:66-76.

Nielsen HM, Veerhuis R, Holmqvist B, Janciauskiene S (2009) Binding and uptake of A beta1-42 by primary human astrocytes in vitro. Glia 57:978988.

Oakley H, Cole SL, Logan S, Maus E, Shao P, Craft J, Guillozet-Bongaarts A, Ohno M, Disterhoft J, Van Eldik L, Berry R, Vassar R (2006) Intraneuronal beta-amyloid aggregates, neurodegeneration, and neuron loss in transgenic mice with five familial Alzheimer's disease mutations: potential factors in amyloid plaque formation. J Neurosci 26:1012910140.

Orellana JA, Shoji KF, Abudara V, Ezan P, Amigou E, Saez PJ, Jiang JX, Naus CC, Saez JC, Giaume C (2011) Amyloid beta-induced death in neurons involves glial and neuronal hemichannels. J Neurosci 31:4962-4977.

Orr AG, Hsiao EC, Wang MM, Ho K, Kim DH, Wang X, Guo W, Kang J, Yu GQ, Adame A, Devidze N, Dubal DB, Masliah E, Conklin BR, Mucke L (2015) Astrocytic adenosine receptor A2A and Gs-coupled signaling regulate memory. Nat Neurosci 18:423-434.

Orr AG, Lo I, Schumacher H, Ho K, Gill M, Guo W, Kim DH, Knox A, Saito T, Saido TC, Simms J, Toddes C, Wang X, Yu GQ, Mucke L (2018) Istradefylline reduces memory deficits in aging mice with amyloid pathology. Neurobiol Dis 110:29-36.

Prasad H, Rao R (2018) Amyloid clearance defect in ApoE4 astrocytes is reversed by epigenetic correction of endosomal pH. Proc Natl Acad Sci USA 115:E6640-E6649.

Rampe D, Wang L, Ringheim GE (2004) P2X7 receptor modulation of betaamyloid- and LPS-induced cytokine secretion from human macrophages and microglia. J Neuroimmunol 147:56-61.

Rauch SM, Huen K, Miller MC, Chaudry H, Lau M, Sanes JR, Johanson CE, Stopa EG, Burgess RW (2011) Changes in brain beta-amyloid deposition and aquaporin 4 levels in response to altered agrin expression in mice. J Neuropathol Exp Neurol 70:1124-1137.

Rebeck GW, Reiter JS, Strickland DK, Hyman BT (1993) Apolipoprotein E in sporadic Alzheimer's disease: allelic variation and receptor interactions. Neuron 11:575-580.

Riteau N, Baron L, Villeret B, Guillou N, Savigny F, Ryffel B, Rassendren F, Le Bert M, Gombault A, Couillin I (2012) ATP release and purinergic signaling: a common pathway for particle-mediated inflammasome activation. Cell Death Dis 3:e403.

Sampath D, Sathyanesan M, Newton SS (2017) Cognitive dysfunction in major depression and Alzheimer's disease is associated with hippocampal-prefrontal cortex dysconnectivity. Neuropsychiatr Dis Treat 13:15091519.

Sanz JM, Falzoni S, Rizzo R, Cipollone F, Zuliani G, Di Virgilio F (2014) Possible protective role of the $489 \mathrm{C}>\mathrm{T}$ P2X7R polymorphism in Alzheimer's disease. Exp Gerontol 60:117-119.

Sanz JM, Chiozzi P, Ferrari D, Colaianna M, Idzko M, Falzoni S, Fellin R, Trabace L, Di Virgilio F (2009) Activation of microglia by amyloid \{beta\} requires P2X7 receptor expression. J Immunol 182:4378-4385.

Selkoe DJ, Hardy J (2016) The amyloid hypothesis of Alzheimer's disease at 25 years. EMBO Mol Med 8:595-608.

Shaffer LM, Dority MD, Gupta-Bansal R, Frederickson RC, Younkin SG, Brunden KR (1995) Amyloid beta protein (A beta) removal by neuroglial cells in culture. Neurobiol Aging 16:737-745.

Shen C, Xiong WC, Mei L (2015) LRP4 in neuromuscular junction and bone development and diseases. Bone 80:101-108.

Strittmatter WJ, Saunders AM, Schmechel D, Pericak-Vance M, Enghild J, Salvesen GS, Roses AD (1993a) Apolipoprotein E: high-avidity binding to beta-amyloid and increased frequency of type 4 allele in late-onset familial Alzheimer disease. Proc Natl Acad Sci USA 90:1977-1981.

Strittmatter WJ, Weisgraber KH, Huang DY, Dong LM, Salvesen GS, Pericak-Vance M, Schmechel D, Saunders AM, Goldgaber D, Roses AD (1993b) Binding of human apolipoprotein E to synthetic amyloid beta peptide: isoform-specific effects and implications for late-onset Alzheimer disease. Proc Natl Acad Sci USA 90:8098-8102.

Stujenske JM, Likhtik E, Topiwala MA, Gordon JA (2014) Fear and safety engage competing patterns of theta-gamma coupling in the basolateral amygdala. Neuron 83:919-933.

Sun XD, Li L, Liu F, Huang ZH, Bean JC, Jiao HF, Barik A, Kim SM, Wu H, Shen C, Tian Y, Lin TW, Bates R, Sathyamurthy A, Chen YJ, Yin DM, Xiong L, Lin HP, Hu JX, Li BM, et al. (2016) Lrp4 in astrocytes modulates glutamatergic transmission. Nat Neurosci 19:10101018 .

Swanson LW (1981) A direct projection from Ammon's horn to prefrontal cortex in the rat. Brain Res 217:150-154.

Tamamizu-Kato S, Cohen JK, Drake CB, Kosaraju MG, Drury J, Narayanaswami V (2008) Interaction with amyloid beta peptide compromises the lipid binding function of apolipoprotein E. Biochemistry 47:5225-5234

Tan Z, Robinson HL, Yin DM, Liu Y, Liu F, Wang H, Lin TW, Xing G, Gan L, Xiong WC, Mei L (2018) Dynamic ErbB4 activity in hippocampal-prefrontal synchrony and top-down attention in rodents. Neuron 98:380393.e384.

Thal DR, Schultz C, Dehghani F, Yamaguchi H, Braak H, Braak E (2000) Amyloid beta-protein (Abeta)-containing astrocytes are located preferentially near N-terminal-truncated Abeta deposits in the human entorhinal cortex. Acta Neuropathol 100:608-617.

Van Uden E, Mallory M, Veinbergs I, Alford M, Rockenstein E, Masliah E (2002) Increased extracellular amyloid deposition and neurodegeneration in human amyloid precursor protein transgenic mice deficient in receptor-associated protein. J Neurosci 22:9298-9304.

Verghese PB, Castellano JM, Garai K, Wang Y, Jiang H, Shah A, Bu G, Frieden C, Holtzman DM (2013) ApoE influences amyloid-beta (Abeta) clearance despite minimal apoE/Abeta association in physiological conditions. Proc Natl Acad Sci USA 110:E1807-E1816.

Viana da Silva S, Haberl MG, Zhang P, Bethge P, Lemos C, Goncalves N, Gorlewicz A, Malezieux M, Goncalves FQ, Grosjean N, Blanchet C, Frick A, Nagerl UV, Cunha RA, Mulle C (2016) Early synaptic deficits in the APP/PS1 mouse model of Alzheimer's disease involve neuronal adenosine A2A receptors. Nat Commun 7:11915.

Wang H, Liu F, Chen W, Sun X, Cui W, Dong Z, Zhao K, Zhang H, Li H, Xing G, Fei E, Pan BX, Li BM, Xiong WC, Mei L (2018) Genetic recovery of ErbB4 in adulthood partially restores brain functions in null mice. Proc Natl Acad Sci USA 115:13105-13110.

Wen L, Tang FL, Hong Y, Luo SW, Wang CL, He W, Shen C, Jung JU, Xiong F, Lee DH, Zhang QG, Brann D, Kim TW, Yan R, Mei L, Xiong WC (2011) VPS35 haploinsufficiency increases Alzheimer's disease neuropathology. J Cell Biol 195:765-779.

Wisniewski HM, Wegiel J (1991) Spatial relationships between astrocytes and classical plaque components. Neurobiol Aging 12:593600

Wu H, Lu Y, Shen C, Patel N, Gan L, Xiong WC, Mei L (2012) Distinct roles of muscle and motoneuron LRP4 in neuromuscular junction formation. Neuron 75:94-107.

Wyss-Coray T, Loike JD, Brionne TC, Lu E, Anankov R, Yan F, Silverstein SC, Husemann J (2003) Adult mouse astrocytes degrade amyloid-beta in vitro and in situ. Nat Med 9:453-457.

Xiao Q, Yan P, Ma X, Liu H, Perez R, Zhu A, Gonzales E, Burchett JM, Schuler DR, Cirrito JR, Diwan A, Lee JM (2014) Enhancing astrocytic lysosome biogenesis facilitates Abeta clearance and attenuates amyloid plaque pathogenesis. J Neurosci 34:9607-9620.

Xiong L, Jung JU, Guo HH, Pan JX, Sun XD, Mei L, Xiong WC (2017) Osteoblastic Lrp4 promotes osteoclastogenesis by regulating ATP release and adenosine-A2AR signaling. J Cell Biol 216:761-778.

Yamazaki Y, Zhao N, Caulfield TR, Liu CC, Bu G (2019) Apolipoprotein E and Alzheimer disease: pathobiology and targeting strategies. Nat Rev Neurol 15:501-518.

Youmans KL, Leung S, Zhang J, Maus E, Baysac K, Bu G, Vassar R, Yu C, LaDu MJ (2011) Amyloid-beta42 alters apolipoprotein E solubility in brains of mice with five familial AD mutations. J Neurosci Methods 196:51-59.

Youmans KL, Tai LM, Nwabuisi-Heath E, Jungbauer L, Kanekiyo T, Gan M, Kim J, Eimer WA, Estus S, Rebeck GW, Weeber EJ, Bu G, Yu C, Ladu MJ (2012) APOE4-specific changes in Abeta accumulation in a new 
transgenic mouse model of Alzheimer disease. J Biol Chem 287:4177441786.

Zhang B, Luo S, Wang Q, Suzuki T, Xiong WC, Mei L (2008) LRP4 serves as a coreceptor of agrin. Neuron 60:285-297.

Zhang H, Kang E, Wang Y, Yang C, Yu H, Wang Q, Chen Z, Zhang C, Christian KM, Song H, Ming GL, Xu Z (2016) Brain-specific Crmp2 deletion leads to neuronal development deficits and behavioural impairments in mice. Nat Commun 7:11773.

Zhang H, Sathyamurthy A, Liu F, Li L, Zhang L, Dong Z, Cui W, Sun X, Zhao K, Wang H, Ho HH, Xiong WC, Mei L (2019) Agrin-Lrp4-Ror2 signaling regulates adult hippocampal neurogenesis in mice. Elife 8:e45303.

Zhang W, Coldefy AS, Hubbard SR, Burden SJ (2011) Agrin binds to the Nterminal region of Lrp4 protein and stimulates association between Lrp4 and the first immunoglobulin-like domain in muscle-specific kinase (MuSK). J Biol Chem 286:40624-40630.

Zhao K, Shen C, Li L, Wu H, Xing G, Dong Z, Jing H, Chen W, Zhang H, Tan Z, Pan J, Xiong L, Wang H, Cui W, Sun XD, Li S, Huang X, Xiong WC, Mei L (2018) Sarcoglycan alpha mitigates neuromuscular junction decline in aged mice by stabilizing LRP4. J Neurosci 38:8860-8873.

Zhuo L, Theis M, Alvarez-Maya I, Brenner M, Willecke K, Messing A (2001) hGFAP-cre transgenic mice for manipulation of glial and neuronal function in vivo. Genesis 31:85-94.

Zong Y, Zhang B, Gu S, Lee K, Zhou J, Yao G, Figueiredo D, Perry K, Mei L, Jin R (2012) Structural basis of agrin-LRP4-MuSK signaling. Genes Dev 26:247-258. 